\title{
Biochemical markers of ongoing joint damage in rheumatoid arthritis - current and future applications, limitations and opportunities
}

\author{
Morten A Karsdal*1,2, Thasia Woodworth ${ }^{3}$, Kim Henriksen', Walter P Maksymowych4, Harry Genant 5 , Philippe Vergnaud ${ }^{5}$, \\ Claus Christiansen', Tanja Schubert ${ }^{5}$, Per Qvist', Georg Schett ${ }^{6}$, Adam Platt ${ }^{7}$ and Anne-Christine Bay-Jensen ${ }^{1}$
}

\begin{abstract}
Rheumatoid arthritis (RA) is a chronic systemic autoimmune disease associated with potentially debilitating joint inflammation, as well as altered skeletal bone metabolism and co-morbid conditions. Early diagnosis and aggressive treatment to control disease activity offers the highest likelihood of preserving function and preventing disability. Joint inflammation is characterized by synovitis, osteitis, and/or peri-articular osteopenia, often accompanied by development of subchondral bone erosions, as well as progressive joint space narrowing. Biochemical markers of joint cartilage and bone degradation may enable timely detection and assessment of ongoing joint damage, and their use in facilitating treatment strategies is under investigation. Early detection of joint damage may be assisted by the characterization of biochemical markers that identify patients whose joint damage is progressing rapidly and who are thus most in need of aggressive treatment, and that, alone or in combination, identify those individuals who are likely to respond best to a potential treatment, both in terms of limiting joint damage and relieving symptoms. The aims of this review are to describe currently available biochemical markers of joint metabolism in relation to the pathobiology of joint damage and systemic bone loss in RA; to assess the limitations of, and need for additional, novel biochemical markers in RA and other rheumatic diseases, and the strategies used for assay development; and to examine the feasibility of advancement of personalized health care using biochemical markers to select therapeutic agents to which a patient is most likely to respond.
\end{abstract}

\section{Introduction}

It is now widely acknowledged that early diagnosis of rheumatoid arthritis (RA) and aggressive treatment to control disease activity offer the highest likelihood of preserving function and preventing disability. RA is a chronic autoimmune disease characterized by polyarticular inflammation associated with synovitis, osteitis, and peri-articular osteopenia, often associated with erosion of subchondral bone and progressive joint space narrowing [1]. These features commonly lead to progressive joint damage, impaired function, and progressive disability [2-4]. Since roughly half of RA patients suffer disability within 10 years of diagnosis, it is critical to effectively treat the disease early to suppress inflammation and prevent destruction of bone and joint

*Correspondence: mk@nordicbioscience.com

'Nordic Bioscience, Herlev Hovedgade 207, DK-2730 Herlev, Denmark

Full list of author information is available at the end of the article cartilage $[5,6]$. Treatment is commonly determined by the extent or severity of disease activity, assessed by counting the number of swollen and tender joints, measuring patient-reported outcomes (for example, patient global quality of life assessment), and assaying acute phase responses, such as the erythrocyte sedimentation rate (ESR) and C-reactive protein (CRP) levels.

While inflammation markers are clinically relevant, markers that reliably detect ongoing bone and cartilage damage are potentially more useful for timely monitoring of efficacy of treatment. Joint inflammation and damage are so far assessed by various imaging methods, including hand and feet radiographs, hand magnetic resonance imaging (MRI), and high-resolution ultrasound of specific joints [7]. Biochemical markers of bone and cartilage turnover are also receiving increasing attention in other conditions characterized by joint and/or skeletal inflammation and damage [8]. They may provide an additional and potentially more sensitive method of detection of active bone and cartilage degradation that is likely to lead to structural damage in RA [0]. 
An evolving line of evidence suggests that markers associated with clinical response may not be the same biomarkers that predict risk of further joint damage, as verified by radiological progression, and thus different marker combinations are likely to be needed, with specific combinations selected for specific uses, potentially contributing to personalized health care [10-12]. Prognostic markers could be divided into at least two categories: those that predict clinical response in terms of signs and symptoms of RA, and those that predict and monitor joint damage, as detected cumulatively by various imaging modalities, and ultimately demonstrated by the clinical manifestations of deformity and dysfunction.

The aims of this review are to describe pathobiology that generates biochemical markers of joint metabolism/ damage in RA, including application in assay development; to survey the current use of biochemical markers of joint damage in RA and some other relevant diseases; to discuss the limitations of some of these established biochemical markers, including the need for further research into serum and urine markers, to encourage optimal study designs and sample acquisition; to describe how biochemical markers may allow for diagnosis of patients who are experiencing joint damage with rapid degradation of bone and/or cartilage and thus are most in need of timely, aggressive treatment; and to discuss how advances in personalized health care, including mapping of a patient's specific biomarker and clinical profile, will allow treatment selection according to those that will be most likely to benefit.

\section{Pathobiological processes associated with progression of joint damage, and biochemical markers of joint damage}

The different cellular phenotypes involved in joints (osteoblasts, osteoclasts, chondrocytes, macrophages, B cells, $\mathrm{T}$ cells, fibrobast-like synoviocytes and macrophages) play distinct complex and inter-related roles in the pathogenesis and progression of RA joint damage [13]. Subchondral bone erosion, sclerosis and articular cartilage degradation leading to joint space narrowing are central features of joint damage in RA. Synovitis and osteitis associated with osteoclast activation and degradation of bone by matrix metalloproteinases (MMPs) and cathepsin $\mathrm{K}$ appear to precede erosions visualized by MRI or radiography [13-17]. Further, cytokines such as IL-1, TNFalpha, IL-6, and IL-17 stimulate chondrocyte activation and expression of MMPs and aggrecanases, resulting in articular cartilage degradation. Thus, a wide range of processes contribute to the pathobiology of joint damage that eventually leads to joint failure [3,10,11,14] (Figure 1). A detailed discussion of the cellular interactions and molecular pathways involved in bone and cartilage damage in RA is out of the scope of this review, and has been documented elsewhere [3,10,12-15,17,].

The generation of a tissue-specific biochemical marker is presented in Figure 2. The enzymes in the inflamed joint generate specific biochemical metabolic products from the extracellular matrix; the actual protein fragments of type II collagen and aggrecan that are the result of pathobiological actions in the joint are schematically presented in Figure 3. These specific products, which will be described, can be measured [7,18], facilitating assessment of various molecular, cellular and pathophysiological processes in the joint. Each marker may provide unique insights into the pathology of the disease by allowing quantitative information on the level of disease activity in terms of target tissue damage, on the action of cytokines driving disease progression, and on the specific mode of action and potential efficacy of therapeutic interventions. These features provide perspective for the characterization of the ongoing pathobiology using sets of biomarkers that potentially describe the type of damage occurring. A combination of specific biomarkers may thus provide more detailed and accurate information on joint pathology and ongoing structural damage than individual markers.

As described above, the biochemical markers may be useful by providing quantitative information on the pathology and unique processes associated with joint damage in RA. In addition, from a patient-management perspective, the biochemical markers may be useful for the diagnosis of patients with ongoing, active damage to, and degradation of, bone and/or cartilage, for early detection and monitoring of response to treatment, and for personalizing health care. Patients with such ongoing, active damage and degradation of bone and/or cartilage might be classified as 'rapid progressors' and are those most in need of effective treatment. They may be identified by detection of abnormal serum and/or urine levels of bone, synovium and/or cartilage degradation/turnover markers, prior to established, irreversible damage being identified using one or more imaging modalities. Early detection and monitoring of response to treatment potentially provides more rapid verification of control of joint damage than improvement in clinical symptoms or imaging changes, since a minimum of 6 months is needed to ascertain radiological progression, although newer MRI technologies may detect changes in osteitis and synovitis within several months. Health care can be personalized by identifying patients most likely to respond or not to a particular treatment, thus enabling informed selection of an appropriate therapeutic agent, as well as timely verification of its expected efficacy.

\section{Biochemical markers as predictors of progression of structural damage}

Biochemical markers of bone turnover have been used as standard practice to measure the effects of therapy in 


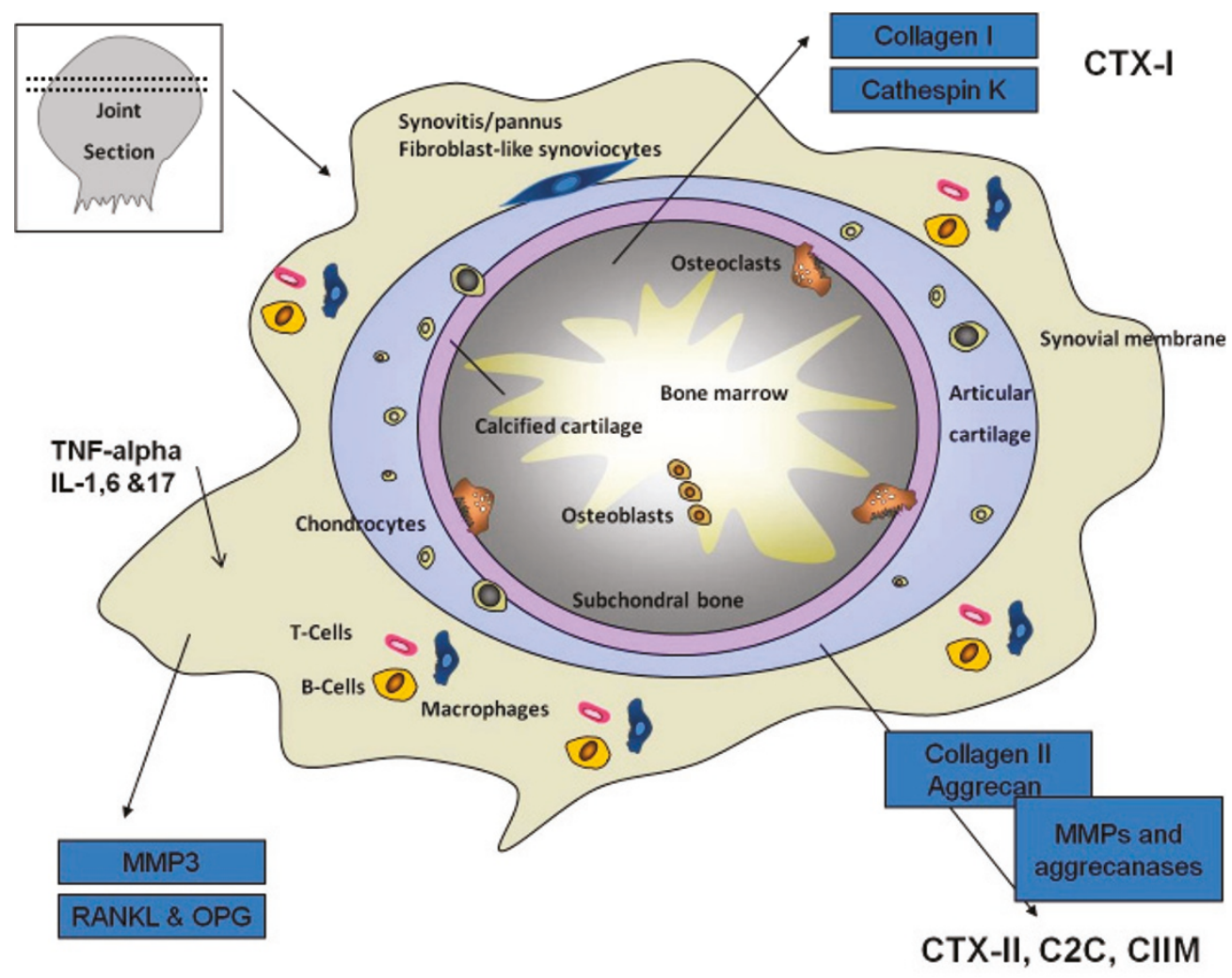

Figure 1. Cells involved in rheumatoid arthritis joint damage include osteoblasts, osteoclasts, chondrocytes, monocytes/macrophages, B cells, T cell subsets (including regulatory $T$ cells), and fibrobast-like synoviocytes, each playing distinct complex and interrelated roles in its pathogenesis and progression. This cellular diversity highlights the need for biomarkers for a range of pathological events. Different markers of cell signaling (for example, receptor activator of NF-kB ligand (RANKL) and osteoprotegerin (OPG)), cell differentiation, collagen I and II degradation and turnover, matrix production, and matrix degradation and the enzymes mediating that degradation may be measured. The pleiotrophic cytokines IL-1 $\beta, T N F-a, I L-6$, and IL-17, as well as several other cytokines and chemokines, are associated with the induction of matrix metalloproteinases (MMPs), as well as osteoclast differentiation, activation and release of cathepsin $\mathrm{K}$ [36]. This range of interactive events leads to progressive joint destruction if not managed attentively, for example, using tight control strategies $[15,18,22,104,140,141]$. C2C, type II collagen fragment; CIIM, MMP mediated type II collagen degradation; CTX-I, C-terminal telopeptide of collagen type I; CTX-II, C-terminal telopeptide of collagen type II.

osteoporosis (OP), a slowly progressing condition [17]. For example, early changes in CTX-I (C-terminal telopeptide of collagen type I), a marker of bone resorption, and changes in osteocalcin, a marker of bone formation, can be used to predict increases in bone mineral density [8]. In contrast to imaging techniques, biochemical markers of bone and cartilage turnover, measured in serum or urine samples collected during fasting or as second morning void specimens, show clinically relevant changes over a larger range compared with the imprecision of the assay (8\% to 10\%) [17]. A typical decrease of 50 to $80 \%$ or an increase of 100 to $200 \%$ is observed in the level of biochemical markers within days to weeks after initiation of treatment with anti-resorptive or anabolic drugs [17]. However, the respective change in bone mass ranges from 6 to $7 \%$ after 2 years of bisphosphonate therapy, which is a comparatively small increment relative to a precision error of 1 to $2 \%$ for bone mineral density (BMD) measurements, as reviewed recently [17], and thus could be considered inferior to the dynamic range observed with biochemical markers. Because biochemical markers are sensitive and dynamic indicators of tissue turnover, they have the potential to provide information on treatment efficacy more rapidly than a variety of imaging methods (Figure 4) [16]. This use of biochemical markers of bone turnover has so far been validated in $\mathrm{OP}$, as have markers of cartilage turnover in osteoarthritis (OA) $[8,17]$. In OP, a dynamic biochemical marker such as CTX-I changes within days of initiating treatment with anti-resorptives or the anti-receptor activator of NF-kB ligand (RANKL) drug denosumab, whereas BMD improvements can only be reliably detected over 6 to 12 months. Similarly, urinary CTX-II (C-terminal telopeptide of collagen type II) levels have been shown to predict articular cartilage degradation [19] in OA. The same markers have been examined in RA 


\section{Whole Tissue Pathophysiology}

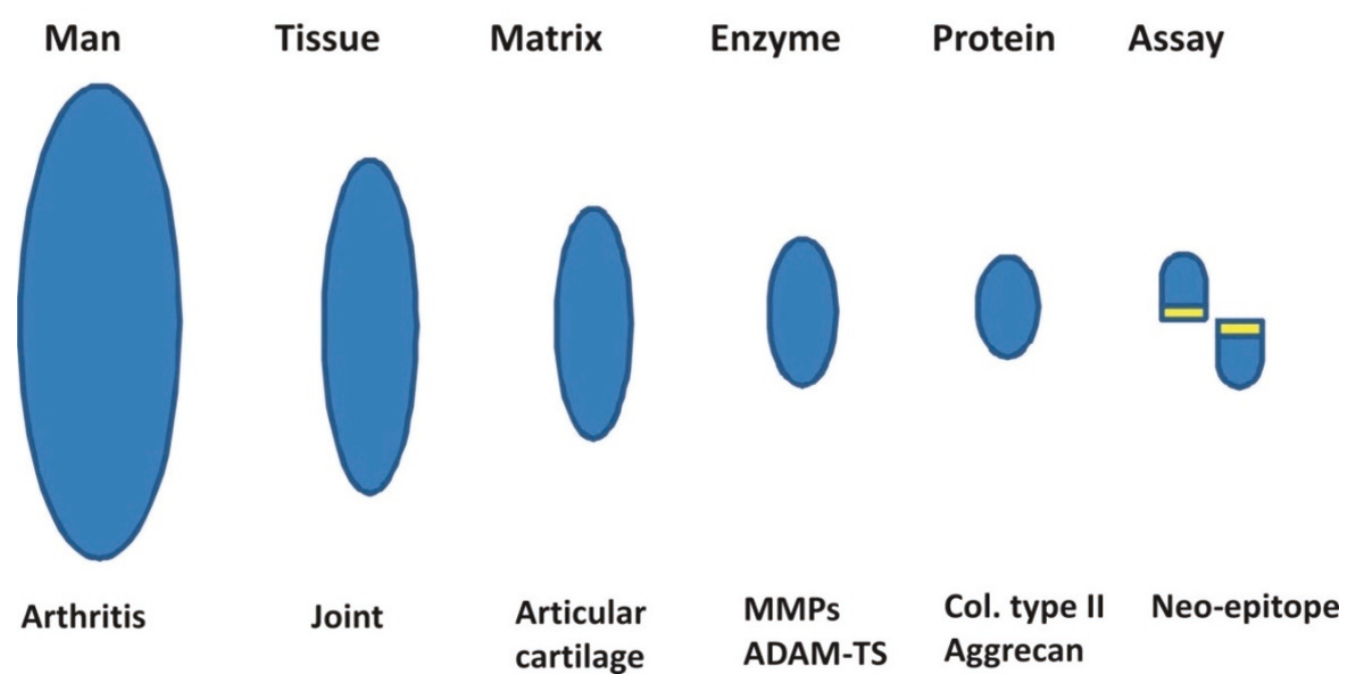

Figure 2. A graphic representation of the generation of pathology-relevant neoepitopes of inflamed joint cartilage. The enzymes presently receiving the most attention are the matrix metalloproteinases (MMPs) and aggrecanases (ADAM-TS (a disintegrin and metalloproteinase with thrombospondin motifs)). The most abundant cartilage proteins are collagen type II and aggrecan. Protease-generated fragments of collagen type II and aggrecan produced through the action of these important enzymes, which may be relevant molecules in tissue destruction, can be used to monitor tissue turnover. These fragments, such as C-terminal telopeptide of type II collagen (CTX-II), may be used in clinical settings, in preclinical models and in simple ex vivo and in vitro systems. Figure adapted with permission from [8].

[20]. CTX-II as a marker of cartilage (collagen II) degradation and CTX-I as a marker of bone (collagen I) degradation in RA at 4 and 12 weeks have been demonstrated to predict joint damage (Tables 1,2 and 3).

Research efforts are underway to apply these principles to proactive management of RA to enhance the detection and prevention of joint damage. X-ray imaging is the standard technique for diagnosis and measurement of efficacy of therapies aimed at inhibiting joint damage. Further efforts are ongoing to validate the use of MRI in this process, and even combine the use of biochemical markers and imaging modalities [7,21]. In RA, joint damage characterized by subchondral bone erosions and joint space narrowing, rather than BMD as in OP, is measured by various scoring methods applied to X-rays of hands and feet. However, X-ray imaging in both diseases is encumbered by rather low precision and could conceivably benefit from combination with biochemical marker analysis (Figure 4).

\section{Need for biochemical markers to facilitate treatment decisions}

Recently, three biological agents with novel mechanisms of action, rituximab, abatacept and tocilizumab, have become available for the treatment of RA, adding to the armamentarium already containing the approved TNF- $\alpha$ inhibitors (infliximab, etanercept, adalimumab, certolizumab and golimumab). Clinical studies with these agents have demonstrated that they are effective in RA patients who did not respond to treatment with at least one disease-modifying antirheumatic drug (DMARD) and/or TNF inhibitor. In the absence of head-to-head trials, the use of specific biochemical markers may aid in differentiating the onset and/or the magnitude and even duration of efficacy of the different drugs, and in understanding which patient may respond best to a given intervention. The early identification of responders and non-responders to the increasing range of treatments for $\mathrm{RA}$, a disease recognized to lead to loss of function and disability if not aggressively treated, will prove valuable to patients, regulators, healthcare providers and payers. The emphasis in RA management today is on early diagnosis and treatment to prevent the progressive joint deterioration predominantly driven by inflammation [22-24]. Selecting the most appropriate intervention has become increasingly complex because, for example, combinations of some therapies have proven more effective in clinical trials than single agents alone and also because different interventions may be more appropriate than others according to the stage and risk of disease progression in individual patients. In some patients, joint damage progresses slowly over time and then begins to progress in a more rapid and dynamic fashion. In those where inflammation is more severe, structural damage can occur 
(a)

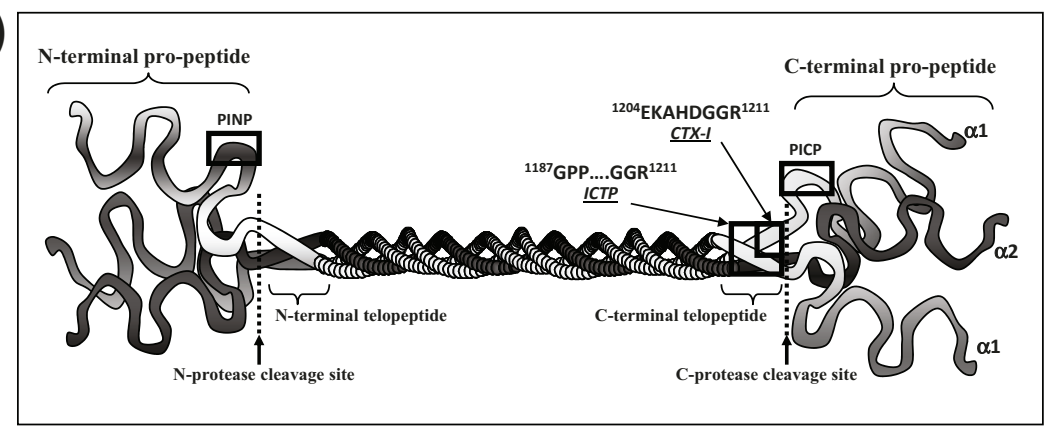

(b)

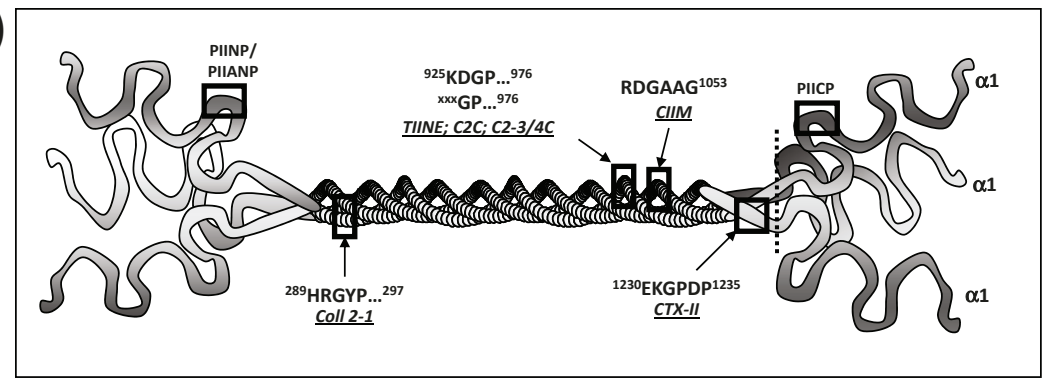

(c)

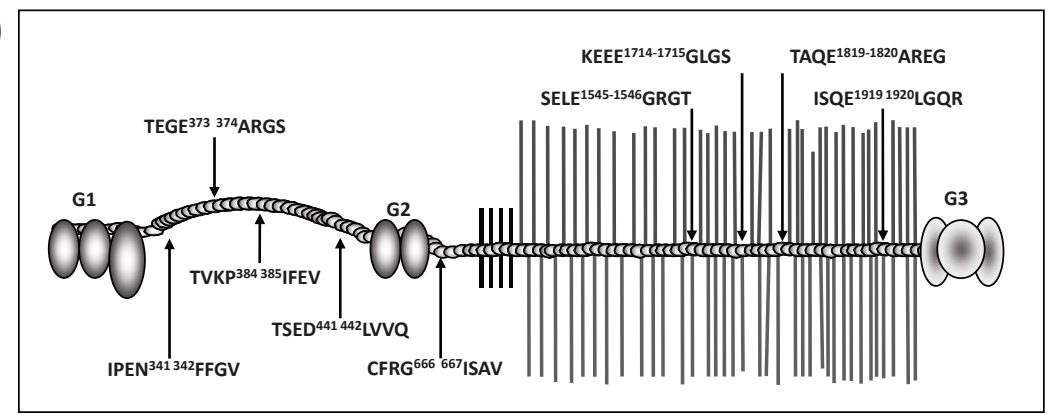

Figure 3. Protease-generated neoepitopes in aggrecan and collagen type I and II. (a,b) The amino- and carboxy-terminal pro-peptides PINP (amino terminus propeptide of type I procollagen), PICP (carboxyl terminus propeptide of type I procollagen), PIINP (amino terminus propeptide of type II procollagen) and PIICP (carboxyl terminus propeptide of type II procollagen) in collagen type I (a) and collagen type II (b) are used to define protein formation, as they are released during formation of the matrix. (a) In contrast, the degradation markers ICTP (type I collagen; MMP mediated) and C-terminal telopeptide of type I collagen (CTX-I; cathepsin-K mediated) located in the carboxy-terminal telopeptide are found in body fluids after degradation of collagen type I. (b) The CTX-II (MMP mediated) degradation marker is located in the carboxy-terminal telopeptide in collagen type II. Coll 2-1, TIINE, C2C, and C2-3/4C are degradation markers located in the helix of collagen type II. (c) The aggrecan molecule is shown with the MMP cleavage sites (upward arrows) and ADAM-TS (a disintegrin and metalloproteinase with thrombospondin motifs) cleavage sites (downward arrows). CIIM is a novel MMP mediated type II collagen degradation marker [142]. Figure adapted with permission from [8].

within just a few months after disease onset. Consequently, the greatest opportunity to change the course of the disease could be through the identification of those patients who either have, or are at risk of developing, rapidly progressive disease. Using biomarkers to predict risk and response to therapy will not only aid the selection of an appropriate, effective intervention for the individual but will also protect patients with less severe disease from possible aggressive over-treatment and toxicities, and may have a significant influence on allocation of health care resources. Several biological markers and clinical indicators have been discovered to identify such patients.

\section{Biochemical markers of joint damage}

Currently, there is no single clinical or laboratory characteristic that identifies RA patients with rapidly progressing joint damage and systemic bone effects. The best-characterized predictors of risk for rapid progression are the number of swollen joints and levels of acutephase reactants such as CRP and ESR. This is not surprising because swollen joints are a clinical manifestation of synovitis, and the acute-phase response acts as a biomarker of pro-inflammatory cytokine production. It is well documented that elevated CRP is associated with increased risk of radiological progression in RA [24,25], and correlation between synovitis and subchondral bone 


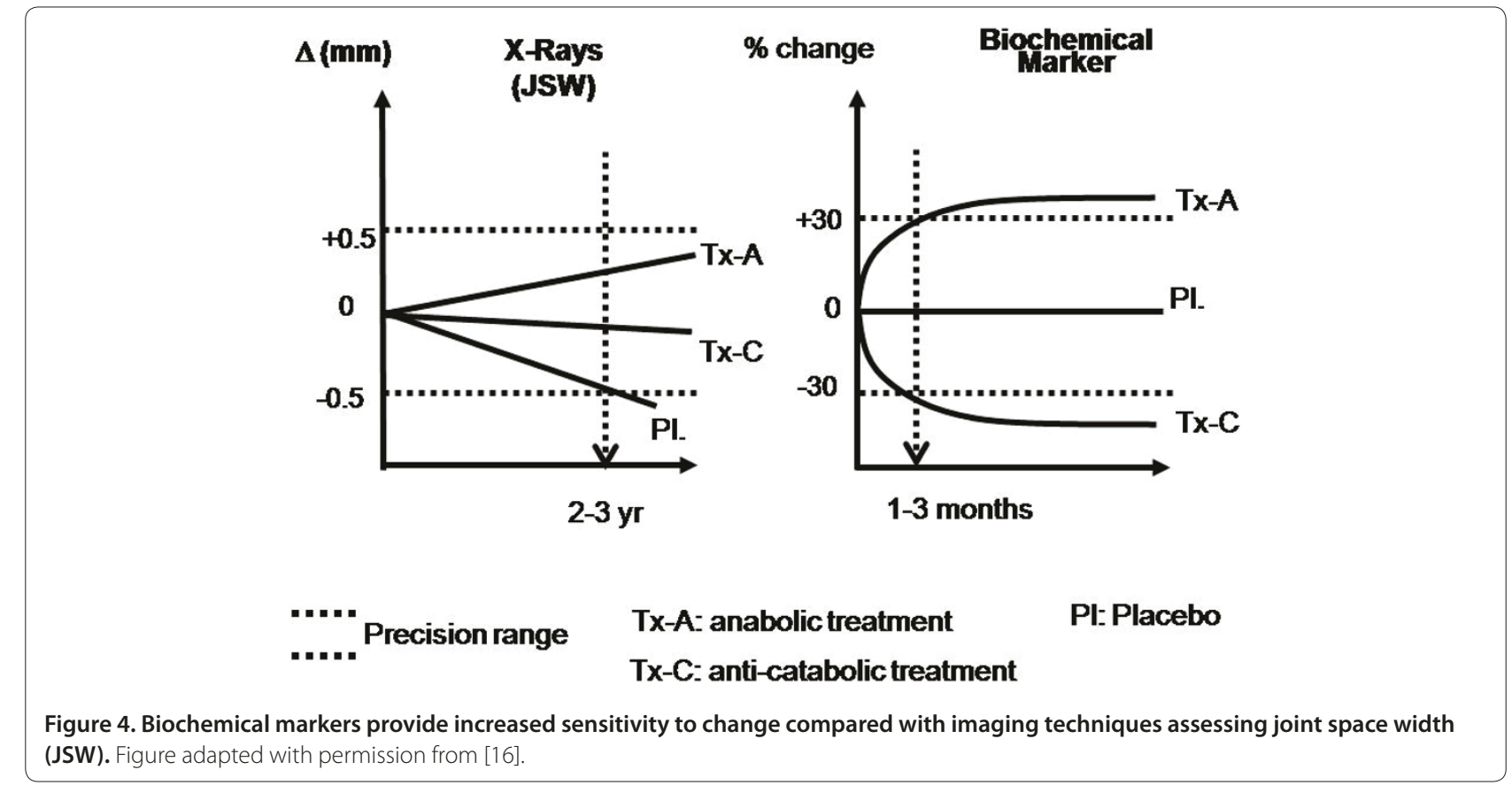

erosions has been established [26-29]. While not all patients with high disease activity that manifests in high swollen joint counts and elevated CRP are immediately eligible for biologic therapy, those who also show ongoing degradation of joint structure proteins may benefit from the most intensive therapy, especially if efficacy can be detected early to manage benefit and risk considerations [25]. The focus of research into joint damage biomarkers has been the identification of proteins that might be surrogates of whole tissue metabolism and of bone and cartilage loss. One approach to identifying pathologically relevant molecules is to combine tissue-specific protein markers with the pathological expression of proteolytic enzymes. The action of enzymes on extracellular matrix components results in matrix degradation fragments, or neoepitopes. The most abundant molecules in the articular cartilage extracellular matrix are collagen type II and aggrecan. These proteins are sequentially degraded when cartilage damage occurs in either RA or OA. Proteasegenerated fragments of collagen type II and aggrecan produced by MMPs and aggrecanases (ADAM-TS) are considered relevant molecules in cartilage degradation [8] (Figure 3). Whole joint tissue pathophysiology may be assessed by the one or more markers of cartilage degradation, but these are only a subset of a larger panel of markers that provide information on bone and inflamed synovial tissue in the joint (Table 1).

As also described in Table 1, additional cartilage degradation markers are becoming available, aimed at more accurate and precise detection of articular cartilage damage. Specific fragments of cartilage proteins have been identified as specific markers of joint damage. Much of this work has been applied according to the US Food and Drug Administration critical path for the development of biochemical markers in translational research [8], where such markers may be applied in both preclinical and clinical research settings.

\section{Joint turnover markers}

Inflammatory joint diseases such as RA lead to alterations in the metabolism of the articular cartilage and subchondral as well as periarticular bone [30-35]. Unique markers have been developed, and others are under development, to reflect different pathobiologic processes. How these processes occur at different stages in the pathogenesis, and result in unique metabolic products of joint inflammation, is discussed in the sections below.

\section{Cartilage turnover markers}

Cartilage turnover normally occurs in a controlled fashion, with a balance between degradation and formation. However, in the inflamed joint, an imbalance is skewed towards degradation rather than formation [36]. Formation and degradation can be monitored by measuring several unique molecules generated during cartilage degradation and turnover [17]. Cartilage is predominantly composed of collagen type II (comprising 60 to $70 \%$ of the dry weight of cartilage) and proteoglycans (10\% of dry weight), of which aggrecan is the most abundant [37]. The key mediators of cartilage degradation include the MMPs and the closely related aggrecanases, which are members of the ADAM-TS family [38,39]. 


\begin{tabular}{ll} 
Assay & Target mo \\
\hline KS/mAb OA-1 & Aggrecan \\
CS846 & Aggrecan \\
$342-G 2$ & Aggrecan \\
& \\
G1-G2 & Aggrecan
\end{tabular}

Serum CRP C-reactive protein

COMP Cartilage oligomeric protein

PICP

PINP

NTX-I

ICTP

PIINP

PIIANP

CP\|

9A4/5109

CTX-II

UTIINE

HELIX-II

C2C

$\mathrm{C} 1, \mathrm{C} 2$

PIIINP
Carboxyl terminus propeptide of type I procollagen

Amino terminus propeptide of

Type I collagen

Type I collagen

Type I collagen

Amino terminus propeptide of type II procollagen

Amino terminus propeptide of type II procollagen, splice variant $A$

C-propeptide of type II collagen

Type II collagen

Type II collagen

Type II collagen

Type II collagen

Type II collagen fragment

Type II collagen fragment

Amino terminus propeptide of type III procollagen type I procollagen

\section{Short description}

Cartilage degradation. Sandwich ELISA using mAb to keratan sulfate and mAb OA-1 to AGase neoepitope ARGSVIL [143]. Detection of fragments in human synovial fluid [143]

Cartilage turnover. mAb aHFPG-846 (lgM) recognizing chondroitin sulfate moieties on aggrecan. Manufacturer: Ibex, Canada

Cartilage degradation. Sandwich ELISA using mAb AF28 binding to the neoepitope 342FFGVG and monoclonal antibody F78 binding to G1/G2 for detection of MMPgenerated aggrecan fragments

Cartilage turnover. Sandwich ELISA using mAb F78 binding to G1/G2 both as capture and detector antibody for detection of intact aggrecan and all aggrecan fragments carrying G1 and/or G2

General inflammation. CRP, an acute phase protein, the assay for which is highly sensitive to detect small changes in magnitude of inflammation

Cartilage turnover. Competition ELISA using polyclonal antibodies [58]. However, sandwich ELISA based on two monoclonal antibodies recognizing different antigenic determinants is described [150]. Manufacturer: AnaMar Medical, Sweden

Evidence of potential usefulness

Bone formation. RIA using polyclonal antibodies raised to fibroblast PICP digested with bacterial collagenase [156]. Manufacturer: Orion Diagnostic, Finland

Bone formation. RIA using polyclonal antibodies recognizing PINP [157]. Manufacturer: Orion Diagnostic, Finland. Electrochemiluminecense using mAbs to PINP. Manufacturer: Roche Diagnostics, Germany

Bone resorption. A sandwich ELISA using $\mathrm{mAb} F 1103$ and F12, both binding to a cathepsin K-derived C-telopeptide neoepitope EKAHD- $\beta$-GGR, where D- $\beta$ - G denotes an isomerized linkage between D and G [84]. Manufacturer: IDS, UK. Also available in an automated version (manufacturer: Roche Diagnostics, Germany)

Bone resorption. ElA detecting a fragment of the $\mathrm{N}$-telopeptide of type I collagen. Manufacturer: Inverness, US

MMP-mediated type I collagen type degradation. RIA detecting a fragment of the C-telopeptide of type I collagen. Manufacturer: Orion Diagnostic, Finland located in the amino-terminal propeptide of type II procollagen [46]

Cartilage formation. An ELISA using rabbit polyclonal antibodies raised to recombinant exon-2 of the amino-terminal propeptide of type II procollagen

Cartilage formation. EIA using rabbit polyclonal antibodies binding to the C-propeptides of type II collagen, that is, a marker of collagen synthesis. Manufacturer: Ibex, Canada containing the carboxyl terminus of the long three-quarter fragment. mAb $\overline{5109 \text { detects }}$ the first underlined sequence, mAb 9A4 the second (neoepitope)

Cartilage degradation. Competition ELISA using mAb F4601 recognizing the C-telopeptide neoepitope EKGPDP (manufacturer: IDS, UK) and mAb 2 B4 recognizing the C-telopeptide neoepitope EKGPDP

Cartilage degradation. An LC-MS/MS assay using mAb 5109 (see above) to affinity purify fragments subjected to MS/MS. Detects a collagenase-derived 45-mer containing the carboxyl terminus of the long three-quarter fragment

Cartilage degradation. A competition ELISA using polyclonal rabbit antibodies recognizing the neoepitope ${ }^{622}$ ERGETGPP* GTS ${ }^{632}$, where $P^{*}$ denotes hydroxyproline. However, a recent publication has highlighted unspecificities [164]

Cartilage degradation. EIA using a monoclonal antibody recognizing the carboxyl terminus of the three-quarter piece of the degraded alpha1(II) chain. Manufacturer: Ibex, Canada

Collagen degradation. EIA using rabbit polyclonal antibodies binding to the carboxyterminal (COL2-3/4C(short)) neoepitope generated by cleavage of native human type II collagen by collagenases. Cross-reactivity to type I collagen

Collagen type II formation. RIA using polyclonal antibodies recognizing PIIINP. 
Table 1. Continued

\begin{tabular}{|c|c|c|c|}
\hline Assay & Target molecule & Short description & $\begin{array}{l}\text { Evidence of } \\
\text { potential } \\
\text { usefulness }\end{array}$ \\
\hline Glc-Gal-PYD & Glucosyl-galactosyl-pyridinoline & $\begin{array}{l}\text { Synovial inflammation. HPLC method for determination of the non-reducible collagen } \\
\text { cross-linker glucosyl-galactosyl-pyridinium present in synovium and absent in bone } \\
\text { cartilage and other soft tissue }\end{array}$ & [171] \\
\hline Serum HA & Hyaluronic acid & $\begin{array}{l}\text { Cartilage turnover. Based on HA binding protein isolated from bovine cartilage. } \\
\text { Manufacturer: for example, Pharmacia, Sweden }\end{array}$ & \\
\hline YKL-40 & Human glycoprotein 39 & $\begin{array}{l}\text { Cartilage turnover. RIA using polyclonal antibodies to a } 40 \mathrm{kDa} \text { glycoprotein. A combined } \\
\text { monoclonal capture and polyclonal (rabbit) detector sandwich assay is available. } \\
\text { Manufacturer: Quidel Corporation, US }\end{array}$ & {$[172]$} \\
\hline OC & Osteocalcin & Bone formation. Numerous assays available & \\
\hline $\begin{array}{l}\text { MMP-3 and } \\
\text { MMPs }\end{array}$ & Varous cell types & Numerous assays available & {$[173,174]$} \\
\hline DKK1/Sclerostin & Dkk-1 & Measurement of Wnt signaling & {$[175,176]$} \\
\hline TRACP 5a & Macrophages & Inflammation & [111] \\
\hline TRACP 5b & Osteoclasts & $\begin{array}{l}\text { Osteoclast number. mAb to TRAcP } 5 b \text {, which may be specific for osteoclasts but not their } \\
\text { activity }\end{array}$ & $\begin{array}{l}{[74,111} \\
177,178]\end{array}$ \\
\hline Cat K & Osteoclasts & Osteoclast number & {$[110]$} \\
\hline
\end{tabular}

CRP, C-reactive protein; EIA, enzyme immunoassay; HA, hemagglutinin; LC, liquid chromatography; mAb, monoclonal antibody; MMP, matrix metalloproteinase; MS/ MS, tandem mass spectrometry; RIA, radioimmune assay. Modified and extended from [179].

Aggrecan is degraded by both MMPs and aggrecanases, whereas collagen type II is degraded by MMPs [40]. The action of these proteases results in the release of collagen and aggrecan peptide fragments that can be measured by ELISA-type assays both in vitro and ex vivo [17] (Figure 4). Since collagen type II is the most abundant protein in cartilage, several different degradation fragments of collagen type II have been identified as useful for monitoring the impact of joint inflammation on cartilage $[17,41]$.

One example of a novel biochemical marker based on neoepitopes [16] is CTX-II, an MMP-generated neoepitope derived from the carboxy-terminal part of type II collagen [42,43]. Measurement of CTX-II has proven useful for monitoring degradation of type II collagen in experimental models assessing cartilage degradation $[17,42,43]$. Cartilage degradation and formation can be efficiently studied in ex vivo cultured explants of bovine articular cartilage [40,44-47]. In this model, a high rate of cartilage degradation can be induced, for example, by the combination of TNF- $\alpha$ and oncostatin $M$, which induce cartilage degradation in a time- and concentrationdependent manner. The role of MMPs is demonstrated by the abrogation of cytokine- induced CTX-II release by the addition of the MMP inhibitor GM6001, but not the cysteine proteinase inhibitor E64. Further, biochemical studies showed that both MMP-9 and MMP-13 had the ability to generate CTX-II fragments [40]. In addition, immunohistochemical localization of CTX-II revealed that it is highly present in areas corresponding to proteoglycan depletion in TNF- $\alpha$ - and oncostatin Mtreated explants [40]. Additional analysis of CTX-II demonstrated that it was localized in the damaged areas of the articular cartilage [48-50]. In clinical studies, high levels of CTX-II have been shown to be associated with the diagnosis of $\mathrm{OA}$ and to predict progression of RA and OA joint damage [51]. Thus, the assay for this MMPgenerated collagen type II neoepitope, CTX-II, is an example of a clinically and pathologically validated indicator of cartilage degradation, although its responsiveness to therapeutic intervention continues to undergo intensive investigation. With further characterization in prospective clinical trials, the CTX-II assay may provide an example that assays for neoepitopes generated by a specific combination of enzyme and matrix molecules are potentially relevant for monitoring risk of joint damage and impact of therapy. The development of assays to assess cartilage degradation and formation is not limited to just CTX-II (Table 4). Degradation markers include urinary TIINE, serum C2C, C1C2, Coll-2-1, ICTP and HELIX-II, and synthesis markers include PIINP and PIIANP, as they are based on propeptides. COMP and YKL-40 have also been used to assess cartilage degradation, but have also been characterized to detect matrix turnover [17,19,45,47,52-74].

\section{Bone turnover markers}

Bone turnover is a continuous process that ensures calcium homeostasis and bone quality [75]. The total skeleton is completely replaced every 10 years on average, 
Table 2. Biochemical markers in rheumatoid arthritis clinical trials: selected studies evaluating biochemical markers

\begin{tabular}{|c|c|c|c|c|c|}
\hline Reference & $\mathrm{N}$ & Design/study if named & Therapy & Markers evaluated & Results/timeframe \\
\hline$[168]$ & 47 & Open, single arm & Adalimumab & MMP-1,-3; COMP & Decrease at 2 years only \\
\hline$[55]$ & 49 & Open, single arm & Inflixamab (32)/etanercept (17) & COMP & Decrease at 3 months \\
\hline \multirow[t]{5}{*}{ [169] } & 68 & Open, single arm & Inflixamab & Osteocalcin & Increase weeks 2 to 6 \\
\hline & & & & P1NP & Increase weeks 2 to 6 \\
\hline & & & & BAP & No change \\
\hline & & & & CTX-I & No change \\
\hline & & & & ICTP & Decrease week 6 \\
\hline \multirow[t]{4}{*}[170]{} & 102 & Open, single arm & Inflixamab & Osteocalcin & No change \\
\hline & & & & CTX-I & Decrease weeks 14 to 42 \\
\hline & & & & RANKL & Decrease week 14 \\
\hline & & & & OPG & No change \\
\hline \multirow[t]{3}{*}{ [24] } & 144 & $\begin{array}{l}\text { Posthoc, substudy in } \\
\text { DB RCT }\end{array}$ & $\begin{array}{l}\text { Inflixamab (two dose levels) } \\
\text { versus MTX }\end{array}$ & CTX-I & No change \\
\hline & & & & Col2-3/4c & No change \\
\hline & & & & MMP-3 & Decrease week 2 \\
\hline \multirow[t]{6}{*}{ [98] } & 139/138 & $\begin{array}{l}\text { 24-week DB RCT, MTX } \\
\text { versus two dose levels }\end{array}$ & Tocilizumab & Osteocalcin & Increase high dose \\
\hline & & & & CTX-I & Decrease both doses \\
\hline & & & & ICTP & Decrease both doses \\
\hline & & & & PIIANP & Decrease, dose-related \\
\hline & & & & HELIX-II & Decrease, dose-related \\
\hline & & & & MMP-3 & Decrease, dose-related \\
\hline$[171]$ & $132 / 124$ & DMARD monotherapy & $\begin{array}{l}\text { Sulfasalazine, MTX, and } \\
\text { adjunctive corticosteroids }\end{array}$ & $\begin{array}{l}\text { MMPs, TIMP-1 COMP, } \\
\text { glu-gal-pyr CTX-II }\end{array}$ & $\begin{array}{l}2 \text { years, AUC measurements; } \\
\text { MMP-3 + CTX-II, AUC was } 81 \% \text { for } \\
\text { predictive accuracy }\end{array}$ \\
\hline$[172]$ & 155 & DMARD monotherapy & $\begin{array}{l}\text { Sulfasalazine, MTX, and } \\
\text { adjunctive corticosteroids }\end{array}$ & CTX-I, CTX-II & $\begin{array}{l}\text { Normalization of CTX-II predicted } \\
\text { RA intervention efficacy }\end{array}$ \\
\hline \multirow[t]{4}{*}[106]{} & 48 & $\begin{array}{l}\text { 1-year, open, single arm } \\
\text { (with BMD) }\end{array}$ & Inflixamab & P1NP & No change weeks 6 and 52 \\
\hline & & & & CTX-I & Decrease week 6 \\
\hline & & & & ICTP & Decrease week 52 \\
\hline & & & & CTX-II & No change \\
\hline \multirow[t]{2}{*}{ [109] } & 66 & $\begin{array}{l}\text { 1-year, open, single arm, } \\
\text { with } X \text {-rays at baseline } \\
\text { and week } 52^{c}\end{array}$ & Inflixamab & CTX-II & No change \\
\hline & & & & Glc-Gal-PYD & No change \\
\hline \multirow[t]{4}{*}[110,111]{} & $145 / 157$ & $\begin{array}{l}\text { 1-year, open RCT/X-rays } \\
\text { (SAMURAI) }\end{array}$ & Tocilizumab (anti-IL-6R) & Osteocalcin & Increase \\
\hline & & & & NTX & Decrease \\
\hline & & & & PIIANPd & Decrease \\
\hline & & & & $M M P-3^{d}$ & Decrease \\
\hline
\end{tabular}

${ }^{\mathrm{a} C}$ Changes with anti-IL-6R evident within 4 to 16 weeks, and at week 24 for CTX-I. bStable bone mineral density at month 12 . 'Patients with progressive joint damage had higher baseline levels. 'With hsCRP, modest correlation with progression of joint damage. AUC, area under the curve; BAP, bone alkaline phosphatase; COMP, cartilage oligomeric protein; CTX-I, C-terminal telopeptide of collagen type I; CTX-II, C-terminal telopeptide of collagen type II; DB, double blinded; DMARD, diseasemodifying antirheumatic drug; hsCRP, high-sensitive CRP; ICTP, type I collagen; MMP, matrix metalloproteinase; MTX, methotrexate; NTX, N-terminal telopeptide of collagen type I; OPG, osteoprotegerin; PIIANP, amino terminus propeptide of type II procollagen, splice variant A; PINP, amino terminus propeptide of type I procollagen; RA, rheumatoid arthritis; RANKL, receptor activator of NF-kB ligand; RCT, randomized controlled trial; TIMP, tissue inhibitor of metalloproteinases.

emphasizing the dynamic nature of this organ and reflecting changes in endocrine function as well as the effects of disease, drugs, and nutritional deficiencies [76]. Perturbation of this delicate balance leads to pathological conditions such as OP and fracture risk, that is, bone loss. Bone turnover is mediated by activated osteoclasts, which degrade the established bone matrix, and osteoblasts, which form new bone matrix, two processes that, under normal circumstances, are tightly coupled and balanced [77]. The primary osteoclast driver is RANKL [78], although co-stimulators such as the cytokines IL-1 $\beta$, IL-6 and/or TNF- $\alpha$ co-stimulate osteoclasts to secrete cathepsin $\mathrm{K}$ into the resorption lacunae $[79,80]$, resulting in degradation of the organic 
Table 3. Biochemical markers in rheumatoid arthritis clinical trials: selected studies evaluating MRI-based measures and biochemical markers

\begin{tabular}{|c|c|c|c|c|c|}
\hline Reference & $\mathrm{N}$ & Design/study if named & Image modality & Markers evaluated & Results \\
\hline$[180]$ & 84 & Longitudinal analysis & MRI and X-ray & $\begin{array}{l}\text { sCTX-I and UCTX-II sOPG, sYKL-40, } \\
\text { sCOMP and sMMP-3 }\end{array}$ & $\begin{array}{l}\text { sCTX-I and UCTX-II were significant } \\
\text { predictors of progressive joint destruction }\end{array}$ \\
\hline$[181]$ & 377 & Cross-sectional analysis & MRI & CTX-II & Correlation of UCTX-II with BME \\
\hline$[155]$ & 98 & Cross-sectional analysis & MRI & COMP, MMP-3, CRP & $\begin{array}{l}\text { COMP was elevated in those with bone } \\
\text { erosions }\end{array}$ \\
\hline
\end{tabular}

BME, bone marrow edema; COMP, cartilage oligomeric protein; CRP, C-reactive protein; CTX-I, C-terminal telopeptide of collagen type I; CTX-II, C-terminal telopeptide of collagen type II; ESR, erythrocyte sedimentation rate; MMP, matrix metalloproteinase; OPG, osteoprotegerin; s, serum; u, urinary; VEGF, vascular endothelial growth factor.

Table 4. Parameters for optimal use and interpretation of markers

\begin{tabular}{|c|c|c|c|c|c|}
\hline Biological parameters & Sampling parameters & Analyte features & Assay format & Assay parameters & Study parameters \\
\hline Food intake [183] & Sample acquisition & Active enzyme & Competitive assay & Dilution recovery & Mode of action \\
\hline Diurnal variation [184-188] & $\begin{array}{l}\text { Sample matrix (serum, } \\
\text { urine, plasma or } \\
\text { synovial fluid) }\end{array}$ & Latent enzyme & Sandwich assay & Buffer robustness & Duration of study \\
\hline Seasonal variation & $\begin{array}{l}\text { Anticoagulant (EDTA, } \\
\text { heparin, citrate) }\end{array}$ & Total protein & $\begin{array}{l}\text { Monoclonal or } \\
\text { polyclonal antibody }\end{array}$ & Range of quantization & Onset of action \\
\hline Joint activity $[189,190]$ & Freeze-thaw cycles & $\begin{array}{l}\text { Fragment of the } \\
\text { protein [9] }\end{array}$ & $\begin{array}{l}\text { Multiplex or other } \\
\text { technique }\end{array}$ & $\begin{array}{l}\text { Sensitivity and limit of } \\
\text { detection }\end{array}$ & $\begin{array}{l}\text { Number of samples, } \\
\text { sampling frequency } \\
\text { (time course) }\end{array}$ \\
\hline Medical condition & $\begin{array}{l}\text { Shipping and storage } \\
\text { conditions }\end{array}$ & & Sample volume & $\begin{array}{l}\text { Specificity and } \\
\text { selectivity of pathology } \\
\text { and parameter }\end{array}$ & Patient population ${ }^{a}$ \\
\hline
\end{tabular}

Compilation of parameters known to influence biological variation or analytic performance of a given biochemical marker. These parameters include, but are not

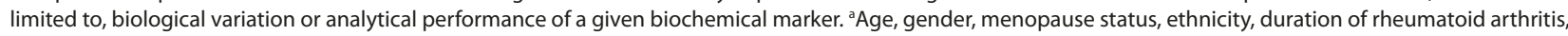
prior treatments such as TNF antagonists, concomitant medications such as corticosteroids, estrogen, SERMs, and bispohosphonates, and comorbidities such as osteoporosis, diabetes, and hypertension with or without renal insufficiency.

matrix of bone. Type I collagen is the most abundant protein in bone [75], and its degradation by cathepsin $\mathrm{K}$ leads to the release of the CTX-I or N-terminal telopeptide of collagen type I (NTX) neoepitope $[81,82]$ (Figure 5). CTX-I levels increase in line with elevated levels of IL- 6 after the menopause, indicating increased osteoclast activity and bone resorption $[83,84]$. CTX-I can be measured in both urine and serum and decreases rapidly in response to anti-resorptive treatment in OP [84-86]. Decreased CTX-I levels within 4 weeks of initiating anti-resorptive therapy correlate with BMD increase at 1 year, demonstrating the efficacy of the intervention [87-89]. As a result, CTX-I is being used in a large number of studies [88-93] to monitor the efficacy of anti-resorptive therapies.

In RA a variety of factors, such as the impact of systemic inflammation, corticosteroid use, and menopause, may influence bone resorption, bone turnover and skeletal status over time. Activated osteoclasts participate in altered bone balance since absence of osteoclasts or absence of osteoclast activities will lead to attenuation of bone resorption but only modest effects on cartilage degradation $[3,94,95]$. The role of cathepsin $\mathrm{K}$ has been extensively studied, and the data are somewhat conflicting for RA [40,96-98]. Levels of cathepsin $\mathrm{K}$ are increased in RA, indicating that it can be used as a marker $[99,100]$, although cathepsin $\mathrm{K}$ does not appear to be the primary enzyme driving bone destruction in RA $[98,101,102]$. CTX-I levels correlate only to some extent with joint damage in RA, and are likely also influenced by loss of skeletal structure/osteopenia/OP, which are also prevalent in RA [22,103,104]. MMPs also play a role in inflammation-associated bone loss $[105,106]$. Studies showing that the MMP-derived collagen type I fragment ICTP is increased in RA may indicate that osteoclasts induce MMP-mediated matrix degradation under these circumstances $[82,107,108]$. Infliximab and tocilizumab treatment have been shown to reduce ICTP levels, as well as osteoclast numbers $[103,109]$, consistent with osteoclast MMP-mediated bone degradation in RA. However, a direct link between the production of ICTP and osteoclasts has not been demonstrated yet.

As illustrated in Figure 5, a range of different markers is available for assessing bone balance in RA. The most 


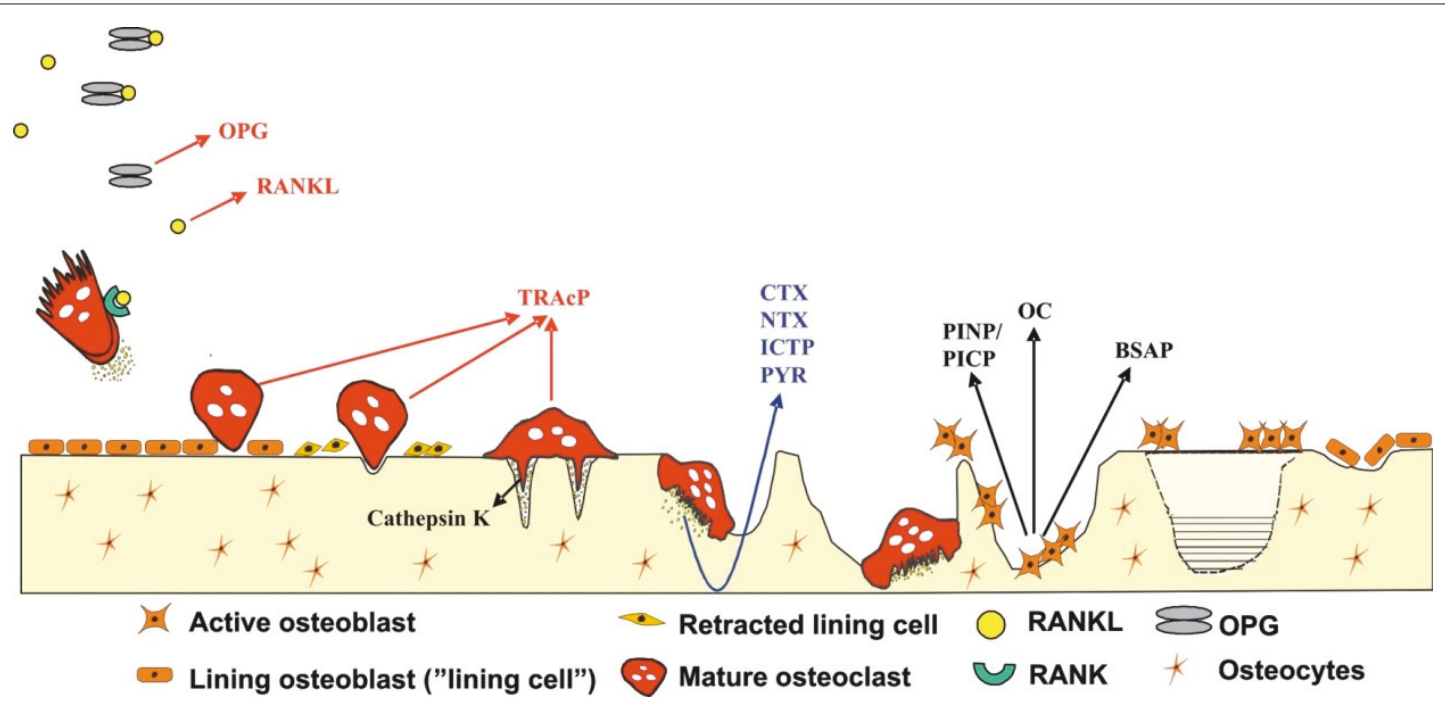

Figure 5. In bone, cell activation, cell differentiation, matrix production, matrix degradation and the enzymes mediating that degradation may be measured by different markers. Each marker provides unique information and may indicate both pathological aspects and serve as a surrogate measure of the mode of action and potential efficacy of therapeutic interventions [85]. BSAP, bone specific alkaline phosphatase; CTX, C-terminal telopeptide of collagen; ICTP, collagen type I fragment; NTX, N-terminal telopeptide of collagen type I; OC, osteocalcin; OPG, osteoprotegerin; PICP, carboxyl terminus propeptide of type I procollagen; PINP, amino terminus propeptide of type I procollagen; RANK, receptor activator of NF-kB; RANKL, receptor activator of NF-kB ligand. Figure adapted with permission from [85].

important markers are those of bone formation (PINP, osteocalcin, bone specific alkaline phosphatase (BSAP)) and bone resorption (for example, NTX and CTX), while assessment of osteoclast numbers by levels of the enzymes TRACP $5 \mathrm{~b}$ and cathepsin $\mathrm{K}$ has more recently provided additional information complementary to bone resorption markers $[74,110]$. Another TRACP isoform, TRACP $5 \mathrm{a}$, is a macrophage marker, and appears to correlate with inflammation [111]. Circulating levels of the formation marker PINP correlate with histomorphometric indices of bone formation [17]. Osteocalcin levels are characteristically low in RA, associated not only with systemic bone loss but also corticosteroid treatment, and levels may stabilize or increase with effective control of inflammation [112-114].

In conclusion, the inflamed joint is composed of several tissues, each of which is subject to degradation and dysregulated collagen and matrix metabolism, in contrast to a normal joint where the balance between formation and degradation is tightly controlled. Changes in biochemical markers generated as a result of dysregulated metabolism may be useful for timely detection of changes in response to treatment in order to limit joint damage and bone loss in RA.

\section{Currently available biochemical markers of joint damage}

The strategy for developing biochemical marker assays has evolved with experience in applying results from disease diagnosis and prognosis as well as from monitoring the effects of treatments for conditions commonly associated with joint damage. The selection of particular assays depends on the objectives for study, but in most settings these include: examination of the mechanism of action to verify potential benefits in limiting joint damage; prediction of risk of joint damage; diagnosis of ongoing bone and/or cartilage degradation in joints; and monitoring for timely detection of onset of action and maintenance of effect to limit joint damage.

Currently available and commonly used biochemical marker assays are described in Table 1. This is not intended to be an exhaustive list; rather, it is intended to orient the reader to assays that have been commonly reported in clinical studies in arthritis, together with several assays that are currently being examined for improvements to meet the above objectives.

\section{Biological marker assays for detection of tissue turnover in the human joint}

Biochemical markers in ankylosing spondylitis - examining unique features of dysregulated bone and cartilage metabolism

Due to the paucity of information provided by standard clinical and laboratory parameters to guide treatment decisions, several of the biomarkers studied in RA have been analyzed in other inflammatory joint diseases, particularly spondyloarthritis (SpA), on the basis that these disorders may share aspects of pathophysiology with RA. There has been particular interest in evaluating biomarkers in AS that reflect disease activity and predict 
structural progression $[13,15,21,115]$. For disease activity, CRP and ESR lack the sensitivity seen in RA, as these markers are elevated in only about 50\% of ankylosing spondylitis (AS) patients [116]. Unlike RA, they also correlate poorly with clinical measures of disease activity, although good correlations have been noted with MRI evidence of inflammation in the spine $[117,118]$. In contrast to RA, they do not appear to predict progression of structural damage, although similar to RA, CRP does predict clinical response to anti-TNF therapy $[119,120]$.

The primary biomarker reflecting tissue turnover related to inflammation in AS that has been analyzed is MMP3. Most studies have shown lower levels of MMP3 in SpA than in RA. Levels are elevated mainly in patients with concomitant peripheral joint inflammation compared to those with only axial inflammation, and levels correlate with the histopathological grade of inflammation $[121,122]$. As for RA, there is evidence that levels of MMP3 can predict progression of radiographic changes, although for AS this means new bone formation rather than the erosive changes documented in RA [123]. This finding is one observation that supports the concept of a link between inflammation and ankylosis in AS. Reductions in MMP3 levels following anti-TNF therapy correlated with reductions in CRP, although MMP3 levels have not been shown to predict clinical response [124].

Biomarkers reflecting cartilage turnover have been analyzed in limited cross-sectional studies of patients with AS. Elevated levels of CPII and the aggrecan 846 epitope were observed, as they were in RA [125], and normalization was seen with anti-TNF therapy [126]. One study has shown that urinary CTX-II may predict progression of structural damage in AS, as also documented for RA [127]. However, unlike RA, the collagen II degradation markers $\mathrm{C} 2 \mathrm{C}$ and $\mathrm{C} 1-2 \mathrm{C}$ were not elevated.

Assessment of biomarkers reflecting bone turnover in SpA have shown variable results depending on the stage and activity of disease, but most studies have reported lower levels for markers of bone resorption than in RA [128]. A major inhibitor of osteoblastogenesis, DKK-1, is markedly elevated in RA but is not predictive in AS [125], while sclerostin is increased in RA and reduced in AS [126]. These changes are consistent with the excess bone formation observed in AS and impaired bone formation in RA.

In the current context, this use of biochemical markers in AS emphasizes that biochemical markers of bone and cartilage may be applied to SpA in well-controlled settings and studies.

\section{Major clinical findings with selected interventions and cohort studies}

Bone and cartilage biomarkers have been used with various levels of success in both degenerative and inflammatory joint disease. Table 2 shows those applicable to RA in combination with X-ray imaging and Table 3 provides the current available publications on MRI and biochemical markers in RA. These tables clearly indicate that a subset of markers have already proven useful for investigating efficacy in RA, although surprisingly few combinations of MRI and biochemical markers are currently used. These tables also do not constitute a full list of relevant studies; important information is available in other publications to complement the condensed information here $[19,20,22,51,104,123,126,127,129-137]$.

\section{Strategies for use of biochemical markers to enhance the benefit:risk ratio of RA therapies}

The lack of consensus on the optimal biochemical marker combination in RA is understandable given the varying outcomes from diverse studies in which their predictive value has been assessed. However, these differing outcomes are likely due, at least in part, to differences in patient populations, such as varying duration of RA, and confounders, such as current and prior treatments, concomitant corticosteroids and other medications, as well as comorbid conditions (Table 4). Typically, studies with biologics with novel and unique mechanisms of action often recruit patients who have failed to respond to one or more therapies and were receiving a variety of concomitant medications. Thus, even though patient populations at first glance may seem somewhat similar, important differences exist and these need to be carefully considered when interpreting results.

Based on our current knowledge on RA, different marker combinations may be useful at different disease stages for identifying severity and risk of progression of joint damage. This concept is illustrated in Figure 6a, and elaborated in Figure 6b-d. However, the use of biochemical marker profiles to identify individual patients who will respond to a particular intervention, or are more likely to experience rapid progression of joint damage, still remains a major challenge.

The pathology of RA appears to consist of a variety of different phenotypes. If RA is left un-segmented and the population treated as a whole, the proportion of patients experiencing remission is relatively low in most clinical trials. As illustrated in Figure 6b, if a biomarker combination can identify a subset of patients representing a given phenotype who will respond to treatment, or demonstrate a superior response to a specific therapeutic intervention, then response rates in this patient subset will be far greater than those in the unstratified population. This is an important socio-economic opportunity. By targeting the optimal treatment to patients who will derive the most benefit, the most favorable benefit:risk ratio will be obtained. 


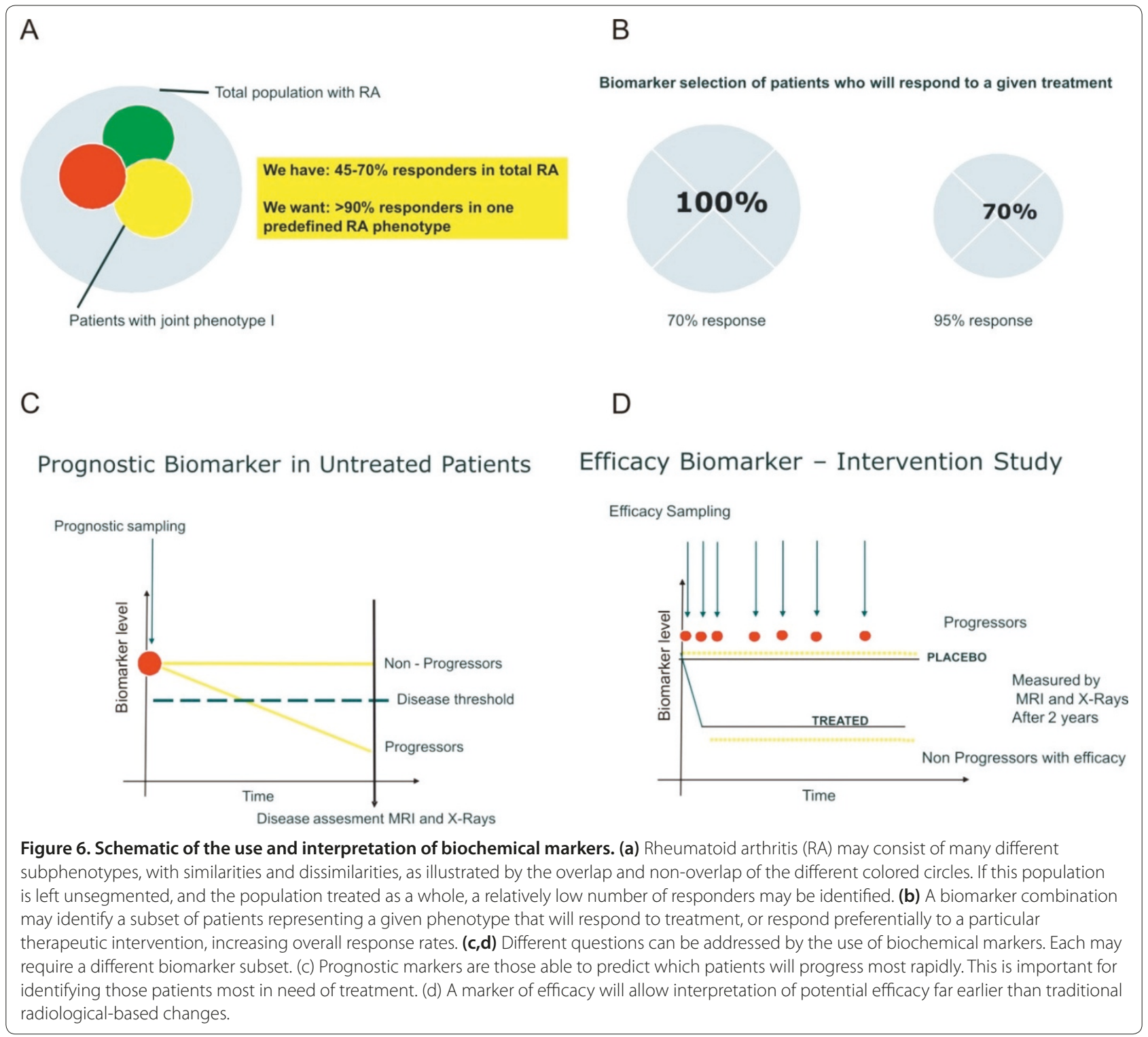

The optimal biomarker combinations for specific purposes and questions need to be carefully investigated, as illustrated in the figures in this paper. Combinations may depend on the duration and stage of disease in addition to the disease activity and associated effects on bone and cartilage tissues. It is now recognized that anti-TNF therapies may limit joint damage, even in clinical nonresponders, and responders to DMARD treatment may continue to experience ongoing joint damage, albeit at a slower rate [23,138]. Thus, a specific combination of biochemical markers may not enable discrimination between clinical responders and non-responders for both radiological progression and patient assessment schemes as outlined by the American College of Rheumatology responder criteria or Disease Activity Score systems. This feature of current therapies remains a further challenge for the use of 'optimal' combinations of biochemical markers and highlights the potential usefulness of biochemical markers of active joint damage.

Lastly, as illustrated in Figure 6c,d and as discussed for the Burden of Disease, Investigative, Prognosis, Efficacy of Intervention and Diagnostic (BIPED) categorization of biochemical markers [139], different questions can be addressed by using these tools. As illustrated in Figure 6c, prognostic markers are those able to predict who will progress most rapidly. This is an important part in identification of those in most need of treatment. The prognostic marker may also allow for identification of particular patient phenotypes that will respond to treatment (Figure 6a,b). A marker of efficacy as illustrated in Figure $6 \mathrm{~d}$ is a measurement at baseline or a temporal measurement compared to baseline, allowing the 
interpretation of potential efficacy ahead of traditional radiological-based techniques, such as illustrated in Figure 2. In particular, in the field of certain bone diseases, CTX-I is a surrogate marker of efficacy, aiding the prediction of a patient's response to treatment before standard radiological assessment is possible [16].

\section{Biomarker classification}

Not all biochemical markers provide the same information. Some may be diagnostic, whereas others may aid prognosis, and others indicate the potential efficacy of interventions. Thus, one biomarker that may fail in one function or scenario may provide important information in another. This highlights the need for a framework to understand terminologies in the development and use of biochemical markers. The recently proposed BIPED classification, developed by the Osteoarthritis Biomarkers Network, which is funded by the US National Institutes of Health, has further highlighted the need for understanding biomarkers and their use [139]. The BIPED classification provides specific biomarker definitions with the goal of improving the development and analysis of OA biomarkers and of communicating advances within a common framework. Briefly, the five definitions for OA are burden of disease, investigative, prognostic, efficacy of intervention, and diagnostic. Burden of disease markers assess the severity or extent of disease, for example, severity within a single joint and/or the number of joints affected. Investigative is an investigative marker with insufficient information to allow inclusion into one of the existing biomarker categories. The investigative category includes markers for which a relationship to various normal and abnormal parameters of cartilage extracellular matrix turnover has not yet been established in human subjects. The key feature of a prognostic marker is the ability to predict the future onset of OA among persons without $\mathrm{OA}$ at baseline or the progression of OA among those with the disease. An efficacy of intervention biomarker provides information about the efficacy of treatment among persons with OA or those at high risk for development of OA. Diagnostic markers are defined by the ability to classify individuals as either having or not having a disease.

This very simple yet elegant classification could be used in other disease indications, such as RA, to foster optimal use, and avoid miscommunication of the benefits of selected biochemical markers.

\section{Confounders that influence the application and interpretation of biochemical marker assay results}

As many factors affect the measurement and interpretation of changes in levels of biochemical markers, a critical review of sample acquisition, storage and assay parameters must be undertaken to optimally assess the reliability of biochemical marker analysis. Some of these considerations are highlighted in Table 4, and the reader is referred to the referenced papers for an in-depth discussion of the individual assays and guidance for appropriate, evidence-based interpretation of their results. Multiple biological or analyte-related factors, assay specifications, study parameters and the context in which the results are interpreted are often underestimated and ignored in the study design phase but can have tremendous impact on the final interpretation of the results.

Technical performance strategies for reproducible and reliable biochemical marker analysis include, but are not limited to, the following parameters. The analytical method must be validated by the laboratory for each biomarker used in a clinical study before the laboratory begins analyzing samples from the study. Although manufacturers' kit inserts provide useful assay parameters, it is mandatory that each laboratory verifies it can reproduce these parameters. The validation should be performed on the same sample matrix (serum, plasma, urine or synovial fluid) as collected in the clinical study. Results obtained from serum are not necessarily the same as those from plasma, for example. The analytical validation should include calibration curves, with at least six non-zero standards, intra- and inter-precisions and accuracy, the range of quantification and sensitivity (lower and upper limits of quantification, limit of detection, specificity and selectivity, recovery, stability and dilution linearity. Theoretically, to estimate intraand inter-run accuracy and stability, five different validation samples should be analyzed in duplicate or more in at least six different runs. One of the major problems with assays (especially microtiter plate-based assays) is reagent-lot variation, indicating a lack of assay robustness. Quality control (QC) samples with predefined validated ranges must be analyzed together with the calibrators and the study sample in each run. These QC samples must be prepared in the same matrix as the study samples and, whenever possible, must cover the range of the standards curve (lower, middle and upper limits). The run must be accepted (or rejected) based on the QC acceptance criteria (typically, a 4-6-X rule, where $\mathrm{X}$ is a selected percent deviation from nominal value), but also on the results of the calibration standards (backcalculated value within $20 \%$ of nominal). Lastly, whenever possible, batches of samples collected during the first visits of the patients, when changes in biomarker levels in response to drug treatment could be theoretically detected, should be assayed together in the same run. This should further minimize inter-assay variation.

These examples serve to highlight that biochemical marker analysis includes a range of parameters that need to be carefully considered and accounted for in optimal 
assay performance, which eventually will impact the results of the clinical trials.

\section{Conclusion}

$\mathrm{RA}$ is often characterized by progressive joint damage that, if not arrested by treatment, often leads to substantial limitation of function and progressive disability. It is evident that the nature of progressive joint damage varies considerably, with some RA patients experiencing more rapid progression than others, based on underlying pathobiology, levels of response to treatment, duration and stage of disease, as well as comorbidities and concomitant medications. Patients with rapidly progressing joint damage may particularly benefit from early aggressive treatment with a biologic agent. Consequently, the identification of patients with ongoing joint damage and assurance that treatment is limiting cartilage degradation and improving bone balance is important in preventing irreversible joint damage. Biological markers and clinical measures can be used to help identify this group of patients, including elevated CRP levels and the number of swollen and tender joints. Additional application of biochemical markers, which are able to sensitively detect ongoing joint damage, may facilitate the appropriate use of targeted therapy in RA and help reduce the progression of joint damage in these patients.

\section{Abbreviations}

ADAM-TS, a disintegrin and metalloproteinase with thrombospondin motifs; AS, ankylosing spondylitis; BIPED, Burden of Disease, Investigative, Prognostic Efficacy of Intervention, Diagnostic classification; BMD, bone mineral density; COMP, cartilage oligomeric protein; CRP, C-reactive protein; CTX-I, C-terminal telopeptide of collagen type I; CTX-II, C-terminal telopeptide of collagen type II; DMARD, disease-modifying antirheumatic drug; ELISA, enzyme-linked immunosorbent assay; ESR, erythrocyte sedimentation rate; IL, interleukin; MMP, matrix metalloproteinase; MRI, magnetic resonance imaging; NTX, $\mathrm{N}$-terminal telopeptide of collagen type I; OA, osteoarthritis; OP, osteoporosis; OPG, osteoprotegerin; QC, quality control; RA, rheumatoid arthritis; RANKL, receptor activator of NF-kB ligand; s, serum; SpA, spondyloarthritis; TNF, tumor necrosis factor; $u$, urinary; VEGF, vascular endothelial growth factor.

\section{Competing interests}

MAK and CC are stockholders of Nordic Bioscience. All others are full time employees of their respective institutions which warrant full disclosure.

\section{Author contributions}

MAK and TW wrote the first draft of the manuscript and outlined the paper with AP. KH wrote sections on bone biology. WPM contributed with sections on AS and general pathophysiology. HG provided valuable imaging advice and discussion. PV and TS wrote assay characteristics and challenges sections. GS provided discussion on pathophysiology and helped outline the manuscript. CC and PQ compiled the current biochemical markers section. ACB-J participated in all aspects of this process. All authors approved the final version of the manuscript.

\section{Acknowledgements}

We gratefully acknowledge funding from the Danish Research Foundation (Den Danske Forskningsfond) supporting this work.

\section{Author details}

${ }^{1}$ Nordic Bioscience, Herlev Hovedgade 207, DK-2730 Herlev, Denmark. ${ }^{2}$ Southern University of Denmark (SDU), Campusvej 55DK-5230 Odense M Denmark. ${ }^{3}$ Leading Edge Clinical Research LLC, 3901 SE St Lucie Blvd unit 20, Stuart, Florida 34997, USA. ${ }^{4}$ University of Alberta, 562 Heritage Medical Research Building, Edmonton, AB T6G 2S2, Canada. ${ }^{5}$ Synarc, 16 Rue Montbrillant, 69003 Lyon, France. ${ }^{6}$ University of Erlangen-Nurnberg Department of Internal Medicine, Krankenhausstraße 12, 91054 Erlangen, Germany. ${ }^{7}$ Roche Products Limited, 6 Falcon Way, Shire Park, Welwyn Garden City, AL7 1TW, UK.

Published: 28 April 2011

\section{References}

1. Avouac J, Allanore Y: Cardiovascular risk in rheumatoid arthritis: effects of anti-TNF drugs. Expert Opin Pharmacother 2008, 9:1121-1128.

2. Diarra D, Stolina M, Polzer K, Zwerina J, Ominsky MS, Dwyer D, Korb A, Smolen J, Hoffmann M, Scheinecker C, van der Heide D, Landewe R, Lacey D, Richards WG, Schett G: Dickkopf-1 is a master regulator of joint remodeling. Nat Med 2007, 13:156-163.

3. Schett G, Hayer S, Zwerina J, Redlich K, Smolen JS: Mechanisms of disease: the link between RANKL and arthritic bone disease. Nat Clin Pract Rheumatol 2005, 1:47-54.

4. Schett G, Stolina M, Bolon B, Middleton S, Adlam M, Brown H, Zhu L, Feige U, Zack DJ: Analysis of the kinetics of osteoclastogenesis in arthritic rats. Arthritis Rheum 2005, 52:3192-3201.

5. Emery P, Breedveld FC, Dougados M, Kalden JR, Schiff MH, Smolen JS: Early referral recommendation for newly diagnosed rheumatoid arthritis: evidence based development of a clinical guide. Ann Rheum Dis 2002, 61:290-297.

6. Furst DE, Keystone EC, Fleischmann R, Mease P, Breedveld FC, Smolen JS, Kalden JR, Braun J, Bresnihan B, Burmester GR, De Benedetti F, Dörner T, Emery P, Gibofsky A, Kavanaugh A, Kirkham B, Schiff MH, Sieper J, Singer N, Van Riel PL, Weinblatt ME, Weisman MH, Winthrop K: Updated consensus statement on biological agents for the treatment of rheumatic diseases, 2009. Ann Rheum Dis 2010, 69 Suppl 1:i2-29.

7. Boesen M, Ostergaard M, Cimmino MA, Kubassova O, Jensen KE, Bliddal H: MRI quantification of rheumatoid arthritis: current knowledge and future perspectives. Eur J Radio/ 2009, 71:189-196.

8. Karsdal MA, Henriksen K, Leeming DJ, Mitchell P, Duffin K, Barascuk N, Klickstein L, Aggarwal P, Nemirovskiy O, Byrjalsen I, Qvist P, Bay-Jensen AC, Dam EB, Madsen SH, Christiansen C: Biochemical markers and the FDA Critical Path: how biomarkers may contribute to the understanding of pathophysiology and provide unique and necessary tools for drug development. Biomarkers 2009, 14:181-202.

9. Bay-Jensen AC, Hoegh-Madsen S, Dam E, Henriksen K, Sondergaard BC, Pastoureau P, Qvist P, Karsdal MA: Which elements are involved in reversible and irreversible cartilage degradation in osteoarthritis? Rheumatol Int 2009, 30:435-442.

10. Meulenbelt I, Kloppenburg M, Kroon HM, Houwing-Duistermaat JJ, Garnero P, Hellio-Le Graverand MP, DeGroot J, Slagboom PE: Clusters of biochemical markers are associated with radiographic subtypes of osteoarthritis (OA) in subject with familial OA at multiple sites. The GARP study. Osteoarthritis Cartilage 2007, 15:379-385.

11. Maksymowych WP, Landewe R, Boers M, Garnero P, Geusens P, El-Gabalawy H, Heinegard D, Kraus VB, Lohmander S, Matyas J, Saxne T, van der Heijde D: Development of draft validation criteria for a soluble biomarker to be regarded as a valid biomarker reflecting structural damage endpoints in rheumatoid arthritis and spondyloarthritis clinical trials. J Rheumato/ 2007, 34:634-640.

12. Bingham CO 3rd, Buckland-Wright JC, Garnero P, Cohen SB, Dougados M, Adami S, Clauw DJ, Spector TD, Pelletier JP, Raynauld JP, Strand V, Simon LS, Meyer JM, Cline GA, Beary JF: Risedronate decreases biochemical markers of cartilage degradation but does not decrease symptoms or slow radiographic progression in patients with medial compartment osteoarthritis of the knee: results of the two-year multinational knee osteoarthritis structural arthritis study. Arthritis Rheum 2006, 54:3494-3507.

13. Schett G, Teitelbaum SL: Osteoclasts and arthritis. J Bone Miner Res 2009, 24:1142-1146.

14. Schett G: Bone marrow edema. Ann N Y Acad Sci 2009, 1154:35-40.

15. Schett G: Erosive arthritis. Arthritis Res Ther 2007, 9 Suppl 1:S2.

16. Karsdal MA, Henriksen K, Leeming DJ, Woodworth T, Vassiliadis E, Bay-Jensen AC: Novel combinations of Post-Translational Modification (PTM) neoepitopes provide tissue-specific biochemical markers - are they the cause or the consequence of the disease? Clin Biochem 2010, 43:793-804. 
17. Schaller S, Henriksen K, Hoegh-Andersen P, Søndergaard BC, Sumer EU, Tanko $\mathrm{LB}, \mathrm{Qvist} \mathrm{P}$, Karsdal MA: In vitro, ex vivo, and in vivo methodological approaches for studying therapeutic targets of osteoporosis and degenerative joint diseases: how biomarkers can assist? Assay Drug Dev Technol 2005, 3:553-580.

18. Schett G: Osteoimmunology in rheumatic diseases. Arthritis Res Ther 2009, 11:210.

19. Dam EB, Byrjalsen I, Karsdal MA, Qvist P, Christiansen C: Increased urinary excretion of C-telopeptides of type II collagen (CTX-II) predicts cartilage loss over 21 months by MRI. Osteoarthritis Cartilage 2009, 17:384-389.

20. Hashimoto S, Creighton-Achermann L, Takahashi K, Amiel D, Coutts RD, Lotz M: Development and regulation of osteophyte formation during experimental osteoarthritis. Osteoarthritis Cartilage 2002, 10:180-187.

21. Dam EB, Loog M, Christiansen C, Byrjalsen I, Folkesson J, Nielsen M, Qazi AA, Pettersen PC, Garnero P, Karsdal MA: Identification of progressors in osteoarthritis by combining biochemical and MRI-based markers. Arthritis Res Ther 2009, 11:R115.

22. Syversen SW, Goll GL, van der Heijde D, Landewé R, Lie BA, Odegård S, Uhlig T, Gaarder PI, Kvien TK: Prediction of radiographic progression in rheumatoid arthritis and the role of antibodies against mutated citrullinated vimentin: results from a 10-year prospective study. Ann Rheum Dis 2010, 69:345-351.

23. Keystone EC, Kavanaugh AF, Sharp JT, Tannenbaum H, Hua Y, Teoh LS, Fischkoff SA, Chartash EK: Radiographic, clinical, and functional outcomes of treatment with adalimumab (a human anti-tumor necrosis factor monoclonal antibody) in patients with active rheumatoid arthritis receiving concomitant methotrexate therapy: a randomized, placebocontrolled, 52-week trial. Arthritis Rheum 2004, 50:1400-1411.

24. Klareskog L, van der Heijde D, de Jager JP, Gough A, Kalden J, Malaise M, Martín Mola E, Pavelka K, Sany J, Settas L, Wajdula J, Pedersen R, Fatenejad S, Sanda M; TEMPO (Trial of Etanercept and Methotrexate with Radiographic Patient Outcomes) study investigators: Therapeutic effect of the combination of etanercept and methotrexate compared with each treatment alone in patients with rheumatoid arthritis: double-blind randomised controlled trial. Lancet 2004, 363:675-681.

25. Breedveld FC, Emery P, Keystone E, Patel K, Furst DE, Kalden JR, St Clair EW Weisman M, Smolen J, Lipsky PE, Maini RN: Infliximab in active early rheumatoid arthritis. Ann Rheum Dis 2004, 63:149-155.

26. Lipsky PE, van der Heijde DM, St Clair EW, Furst DE, Breedveld FC, Kalden JR, Smolen JS, Weisman M, Emery P, Feldmann M, Harriman GR, Maini RN; AntiTumor Necrosis Factor Trial in Rheumatoid Arthritis with Concomitant Therapy Study Group: Infliximab and methotrexate in the treatment of rheumatoid arthritis. Anti-Tumor Necrosis Factor Trial in Rheumatoid Arthritis with Concomitant Therapy Study Group. N Engl J Med 2000 343:1594-1602

27. Maini R, St Clair EW, Breedveld F, Furst D, Kalden J, Weisman M, Smolen J, Emery P, Harriman G, Feldmann M, Lipsky P: Infliximab (chimeric antitumour necrosis factor alpha monoclonal antibody) versus placebo in rheumatoid arthritis patients receiving concomitant methotrexate: a randomised phase III trial. ATTRACT Study Group. Lancet 1999, 354:1932-1939.

28. Smolen JS, Aletaha D: Developments in the clinical understanding of rheumatoid arthritis. Arthritis Res Ther 2009, 11:204

29. Visvanathan S, Marini JC, Smolen JS, Clair EW, Pritchard C, Shergy W, Pendley C, Baker D, Bala M, Gathany T, Han J, Wagner C: Changes in biomarkers of inflammation and bone turnover and associations with clinical efficacy following infliximab plus methotrexate therapy in patients with early rheumatoid arthritis. J Rheumatol 2007, 34:1465-1474.

30. Kerin A, Patwari P, Kuettner K, Cole A, Grodzinsky A: Molecular basis of osteoarthritis: biomechanical aspects. Cell Mol Life Sci 2002, 59:27-35.

31. Karsdal MA, Leeming DJ, Dam EB, Henriksen K, Alexandersen P, Pastoureau $P$, Altman RD, Christiansen C: Should subchondral bone turnover be targeted when treating osteoarthritis? Osteoarthritis Cartilage 2008, 16:638-646.

32. Mansell JP, Collins C, Bailey AJ: Bone, not cartilage, should be the major focus in osteoarthritis. Nat Clin Pract Rheumatol 2007, 3:306-307.

33. van Meurs JB, van Lent PL, Holthuysen AE, Singer II, Bayne EK, Van den Berg WB: Kinetics of aggrecanase- and metalloproteinase-induced neoepitopes in various stages of cartilage destruction in murine arthritis. Arthritis Rheum 1999, 42:1128-1139.

34. Behrens F, Kraft EL, Oegema TR Jr: Biochemical changes in articular cartilage after joint immobilization by casting or external fixation. J Orthop Res 1989,
7:335-343

35. Stoop R, van der Kraan PM, Buma P, Hollander AP, Poole AR, Van den Berg WB: Denaturation of type II collagen in articular cartilage in experimental murine arthritis. Evidence for collagen degradation in both reversible and irreversible cartilage damage. J Pathol 1999, 188:329-337.

36. Goldring MB, Marcu KB: Cartilage homeostasis in health and rheumatic diseases. Arthritis Res Ther 2009, 11:224.

37. Kiani C, Chen L, Wu YJ, Yee AJ, Yang BB: Structure and function of aggrecan. Cell Res 2002, 12:19-32.

38. Glasson SS, Askew R, Sheppard B, Carito B, Blanchet T, Ma HL, Flannery CR, Peluso D, Kanki K, Yang Z, Majumdar MK, Morris EA: Deletion of active ADAMTS5 prevents cartilage degradation in a murine model of osteoarthritis. Nature 2005, 434:644-648.

39. Stanton H, Rogerson FM, East CJ, Golub SB, Lawlor KE, Meeker CT, Little CB, Last K, Farmer PJ, Campbell IK, Fourie AM, Fosang AJ: ADAMTS5 is the major aggrecanase in mouse cartilage in vivo and in vitro. Nature 2005, 434:648-652

40. Sondergaard BC, Henriksen K, Wulf H, Oestergaard S, Schurigt U, Bräuer R, Danielsen I, Christiansen C, Qvist P, Karsdal MA: Relative contribution of matrix metalloprotease and cysteine protease activities to cytokinestimulated articular cartilage degradation. Osteoarthritis Cartilage 2006, 14:738-748.

41. Sumer EU, Schaller S, Sondergaard BC, Tanko LB, Qvist P: Application of biomarkers in the clinical development of new drugs for chondroprotection in destructive joint diseases: a review. Biomarkers 2006, 11:485-506

42. Christgau S, Garnero P, Fledelius C, Moniz C, Ensig M, Gineyts E, Rosenquist C, Qvist P: Collagen type II C-telopeptide fragments as an index of cartilage degradation. Bone 2001, 29:209-215.

43. Mouritzen U, Christgau S, Lehmann HJ, Tanko LB, Christiansen C: Cartilage turnover assessed with a newly developed assay measuring collagen type II degradation products: influence of age, sex, menopause, hormone replacement therapy, and body mass index. Ann Rheum Dis 2003, 62:332-336.

44. Sondergaard BC, Wulf H, Henriksen K, Schaller S, Oestergaard S, Qvist P, Tankó LB, Bagger YZ, Christiansen C, Karsdal MA: Calcitonin directly attenuates collagen type II degradation by inhibition of matrix metalloproteinase expression and activity in articular chondrocytes. Osteoarthritis Cartilage 2006, 14:759-768

45. Sumer EU, Sondergaard BC, Rousseau JC, Delmas PD, Fosang AJ, Karsdal MA, Christiansen C, Qvist P: MMP and non-MMP-mediated release of aggrecan and its fragments from articular cartilage: a comparative study of three different aggrecan and glycosaminoglycan assays. Osteoarthritis Cartilage 2007, 15:212-221.

46. Olsen AK, Sondergaard BC, Byrjalsen I, Tanko LB, Christiansen C, Müller A, Hein GE, Karsdal MA, Qvist P: Anabolic and catabolic function of chondrocyte ex vivo is reflected by the metabolic processing of type II collagen. Osteoarthritis Cartilage 2007, 15:335-342.

47. Karsdal MA, Sumer EU, Wulf H, Madsen SH, Christiansen C, Fosang AJ, Sondergaard BC: Induction of increased CAMP levels in articular chondrocytes blocks matrix metalloproteinase-mediated cartilage degradation, but not aggrecanase-mediated cartilage degradation Arthritis Rheum 2007, 56:1549-1558.

48. Oestergaard S, Chouinard L, Doyle N, Smith SY, Tanko LB, Qvist P: Early elevation in circulating levels of C-telopeptides of type II collagen predicts structural damage in articular cartilage in the rodent model of collageninduced arthritis. Arthritis Rheum 2006, 54:2886-2890

49. Oestergaard S, Sondergaard BC, Hoegh-Andersen P, Henriksen K, Qvist $P_{\text {, }}$ Christiansen C, Tankó LB, Karsdal MA: Effects of ovariectomy and estrogen therapy on type II collagen degradation and structural integrity of articular cartilage in rats: implications of the time of initiation. Arthritis Rheum 2006, 54:2441-2451.

50. Oestergaard S, Chouinard L, Doyle N, Karsdal MA, Smith SY, Qvist P, Tankó LB: The utility of measuring C-terminal telopeptides of collagen type II (CTX-II) in serum and synovial fluid samples for estimation of articula cartilage status in experimental models of destructive joint diseases. Osteoarthritis Cartilage 2006, 14:670-679.

51. Reijman M, Hazes JM, Bierma-Zeinstra SM, Koes BW, Christgau S, Christiansen C, Uitterlinden AG, Pols HA: A new marker for osteoarthritis: cross-sectional and longitudinal approach. Arthritis Rheum 2004, 50:2471-2478.

52. Leeming DJ, Delling G, Koizumi M, Henriksen K, Karsdal MA, Li B, Ovist P, 
Tankó LB, Byrjalsen I: Alpha CTX as a biomarker of skeletal invasion of breast cancer: immunolocalization and the load dependency of urinary excretion. Cancer Epidemiol Biomarkers Prev 2006, 15:1392-1395.

53. Hellio Le Graverand MP, Brandt KD, Mazzuca SA, Katz BP, Buck R, Lane KA, Pickering E, Nemirovskiy OV, Sunyer T, Welsch DJ: Association between concentrations of urinary type II collagen neoepitope (UTIINE) and joint space narrowing in patients with knee osteoarthritis. Osteoarthritis Cartilage 2006, 14:1189-1195.

54. Nemirovskiy OV, Dufield DR, Sunyer T, Aggarwal P, Welsch DJ, Mathews WR: Discovery and development of a type II collagen neoepitope (TIINE) biomarker for matrix metalloproteinase activity: from in vitro to in vivo. Anal Biochem 2007, 361:93-101.

55. Nemirovskiy OV, Sunyer T, Aggarwal P, Abrams M, Hellio Le Graverand MP, Mathews WR: Discovery and development of the $\mathrm{N}$-terminal procollagen type II (NPII) biomarker: a tool for measuring collagen type II synthesis. Osteoarthritis Cartilage 2008, 16:1494-1500.

56. Radabaugh MR, Nemirovskiy OV, Misko TP, Aggarwal P, Mathews WR: Immunoaffinity liquid chromatography-tandem mass spectrometry detection of nitrotyrosine in biological fluids: development of a clinically translatable biomarker. Anal Biochem 2008, 380:68-76.

57. Leeming DJ, Koizumi M, Byrjalsen I, Li B, Qvist P, Tanko LB: The relative use of eight collagenous and noncollagenous markers for diagnosis of skeletal metastases in breast, prostate, or lung cancer patients. Cancer Epidemiol Biomarkers Prev 2006, 15:32-38.

58. Saxne T, Heinegard D: Cartilage oligomeric matrix protein: a novel marker of cartilage turnover detectable in synovial fluid and blood. Br $J$ Rheumatol 1992, 31:583-591.

59. Lohmander LS, Saxne T, Heinegard DK: Release of cartilage oligomeric matrix protein (COMP) into joint fluid after knee injury and in osteoarthritis. Ann Rheum Dis 1994, 53:8-13.

60. Crnkic M, Mansson B, Larsson L, Geborek P, Heinegard D, Saxne T: Serum cartilage oligomeric matrix protein (COMP) decreases in rheumatoid arthritis patients treated with infliximab or etanercept. Arthritis Res Ther 2003, 5:R181-R185.

61. Andersson ML, Thorstensson CA, Roos EM, Petersson IF, Heinegard D, Saxne T: Serum levels of cartilage oligomeric matrix protein (COMP) increase temporarily after physical exercise in patients with knee osteoarthritis. BMC Musculoskelet Disord 2006, 7:98.

62. Karsdal MA, Hjorth P, Henriksen K, Kirkegaard T, Nielsen KL, Lou H, Delaissé JM, Foged NT: Transforming growth factor-beta controls human osteoclastogenesis through the p38 MAPK and regulation of RANK expression. J Biol Chem 2003, 278:44975-44987.

63. Poole AR, Dieppe P: Biological markers in rheumatoid arthritis. Semin Arthritis Rheum 1994, 23:17-31.

64. Bleasel JF, Poole AR, Heinegård D, Saxne T, Holderbaum D, Ionescu M, Jones P, Moskowitz RW: Changes in serum cartilage marker levels indicate altered cartilage metabolism in families with the osteoarthritis-related type II collagen gene COL2A1 mutation. Arthritis Rheum 1999, 42:39-45.

65. Fraser A, Fearon U, Billinghurst RC, lonescu M, Reece R, Barwick T, Emery $P$, Poole AR, Veale DJ: Turnover of type II collagen and aggrecan in cartilage matrix at the onset of inflammatory arthritis in humans: relationship to mediators of systemic and local inflammation. Arthritis Rheum 2003 48:3085-3095

66. Mullan RH, Matthews C, Bresnihan B, FitzGerald O, King L, Poole AR, Fearon U, Veale $D J$ : Early changes in serum type II collagen biomarkers predict radiographic progression at one year in inflammatory arthritis patients after biologic therapy. Arthritis Rheum 2007, 56:2919-2928.

67. Conrozier T, Poole AR, Ferrand F, Mathieu P, Vincent F, Piperno M, Verret C, lonescu M, Vignon E: Serum concentrations of type II collagen biomarkers (C2C, C1, 2C and CPII) suggest different pathophysiologies in patients with hip osteoarthritis. Clin Exp Rheumatol 2008, 26:430-435.

68. Rousseau JC, Zhu Y, Miossec P, Vignon E, Sandell LJ, Garnero P, Delmas PD: Serum levels of type IIA procollagen amino terminal propeptide (PIIANP) are decreased in patients with knee osteoarthritis and rheumatoid arthritis. Osteoarthritis Cartilage 2004, 12:440-447.

69. Kondo $\mathrm{S}$, Cha SH, Xie WF, Sandell $\amalg$ : Cytokine regulation of cartilagederived retinoic acid-sensitive protein (CD-RAP) in primary articular chondrocytes: suppression by IL-1, bfGF, TGFbeta and stimulation by IGF-1. J Orthop Res 2001, 19:712-719.

70. Garnero P, Ayral X, Rousseau JC, Christgau S, Sandell L, Dougados M, Delmas PD: Uncoupling of type Il collagen synthesis and degradation predicts progression of joint damage in patients with knee osteoarthritis. Arthritis Rheum 2002, 46:2613-2624.

71. Rousseau JC, Sandell LJ, Delmas PD, Garnero P: Development and clinical application in arthritis of a new immunoassay for serum type IIA procollagen NH2 propeptide. Methods Mol Med 2004, 101:25-37.

72. Karsdal MA, Madsen SH, Christiansen C, Henriksen K, Fosang AJ, Sondergaard $B C$ : Cartilage degradation is fully reversible in the presence of aggrecanase but not matrix metalloproteinase activity. Arthritis Res Ther 2008, 10:R63.

73. Henriksen K, Sørensen MG, Nielsen RH, Gram J, Schaller S, Dziegiel MH, Everts $\mathrm{V}$, Bollerslev J, Karsdal MA: Degradation of the organic phase of bone by osteoclasts: a secondary role for lysosomal acidification. J Bone Miner Res 2006, 21:58-66

74. Henriksen K, Tanko LB, Qvist P, Delmas PD, Christiansen C, Karsdal MA: Assessment of osteoclast number and function: application in the development of new and improved treatment modalities for bone diseases. Osteoporos Int 2007, 18:681-685.

75. Seeman E, Delmas PD: Bone quality - the material and structural basis of bone strength and fragility. N Eng/ J Med 2006, 354:2250-2261

76. Henriksen K, Bohren KM, Bay-Jensen AC, Karsdal MA: Should biochemical markers of bone turnover be considered standard practice for safety pharmacology? Biomarkers 2010, 15:195-204

77. Karsdal MA, Martin TJ, Bollerslev J, Christiansen C, Henriksen K: Are nonresorbing osteoclasts sources of bone anabolic activity? J Bone Miner Res 2007, 22:487-494

78. Sørensen MG, Henriksen K, Schaller S, Henriksen DB, Nielsen FC, Dziegiel MH, Karsdal MA: Characterization of osteoclasts derived from CD14+ monocytes isolated from peripheral blood. J Bone Miner Metab 2007, 25:36-45.

79. Nishi Y, Atley L, Eyre DE, Edelson JG, Superti-Furga A, Yasuda T, Desnick RJ, Gelb BD: Determination of bone markers in pycnodysostosis: effects of cathepsin K deficiency on bone matrix degradation. J Bone Miner Res 1999, 14:1902-1908.

80. Hou WS, Brömme D, Zhao Y, Mehler E, Dushey C, Weinstein H, Miranda CS, Fraga C, Greig F, Carey J, Rimoin DL, Desnick RJ, Gelb BD: Characterization of novel cathepsin $\mathrm{K}$ mutations in the pro and mature polypeptide regions causing pycnodysostosis. J Clin Invest 1999, 103:731-738.

81. Garnero P, Ferreras M, Karsdal MA, Nicamhlaoibh R, Risteli J, Borel O, Qvist P, Delmas PD, Foged NT, Delaissé JM: The type I collagen fragments ICTP and CTX reveal distinct enzymatic pathways of bone collagen degradation. J Bone Miner Res 2003, 18:859-867.

82. Sassi ML, Eriksen H, Risteli L, Niemi S, Mansell J Gowen M, Risteli J. Immunochemical characterization of assay for carboxytermina telopeptide of human type I collagen: loss of antigenicity by treatment with cathepsin K. Bone 2000, 26:367-373.

83. Bonde M, Qvist P, Fledelius C, Riis BJ, Christiansen C: Applications of an enzyme immunoassay for a new marker of bone resorption (CrossLaps) follow-up on hormone replacement therapy and osteoporosis risk assessment. J Clin Endocrinol Metab 1995, 80:864-868.

84. Rosenquist C, Fledelius C, Christgau S, Pedersen BJ, Bonde M, Qvist P, Christiansen C: Serum CrossLaps One Step ELISA. First application of monoclonal antibodies for measurement in serum of bone-related degradation products from C-terminal telopeptides of type I collagen. Clin Chem 1998, 44:2281-2289.

85. Leeming DJ, Alexandersen P, Karsdal MA, Qvist P, Schaller S, Tanko LB: An update on biomarkers of bone turnover and their utility in biomedical research and clinical practice. Eur J Clin Pharmacol 2006, 62:781-792.

86. Reginster JY, Deroisy R, Rovati LC, Lee RL, Lejeune E, Bruyere O, Giacovelli G, Henrotin Y, Dacre JE, Gossett C: Long-term effects of glucosamine sulphate on osteoarthritis progression: a randomised, placebo-controlled clinical trial. Lancet 2001, 357:251-256.

87. Ravn P, Hosking D, Thompson D, Cizza G, Wasnich RD, McClung M, Yates AJ, Bjarnason NH, Christiansen C: Monitoring of alendronate treatment and prediction of effect on bone mass by biochemical markers in the early postmenopausal intervention cohort study. J Clin Endocrinol Metab 1999, 84:2363-2368

88. Ravn P, Clemmesen B, Christiansen C: Biochemical markers can predict the response in bone mass during alendronate treatment in early postmenopausal women. Alendronate Osteoporosis Prevention Study Group. Bone 1999, 24:237-244

89. Ravn P, Thompson DE, Ross PD, Christiansen C: Biochemical markers for 
prediction of 4-year response in bone mass during bisphosphonate treatment for prevention of postmenopausal osteoporosis. Bone 2003, 33:150-158.

90. McClung MR, Lewiecki EM, Cohen SB, Bolognese MA, Woodson GC, Moffett AH, Peacock M, Miller PD, Lederman SN, Chesnut CH, Lain D, Kivitz AJ, Holloway DL, Zhang C, Peterson MC, Bekker PJ; AMG 162 Bone Loss Study Group: Denosumab in postmenopausal women with low bone mineral density. NEngl J Med 2006, 354:821-831

91. Ravn P, Weiss SR, Rodriguez-Portales JA, McClung MR, Wasnich RD, Gilchrist NL, Sambrook P, Fogelman I, Krupa D, Yates AJ, Daifotis A, Fuleihan GE: Alendronate in early postmenopausal women: effects on bone mass during long-term treatment and after withdrawal. Alendronate Osteoporosis Prevention Study Group. J Clin Endocrinol Metab 2000, 85:1492-1497.

92. Tankó LB, Bagger YZ, Alexandersen P, Devogelaer JP, Reginster JY, Chick R, Olson M, Benmammar H, Mindeholm L, Azria M, Christiansen C: Safety and efficacy of a novel salmon calcitonin (sCT) technology-based oral formulation in healthy postmenopausal women: acute and 3-month effects on biomarkers of bone turnover. J Bone Miner Res 2004, 19:1531-1538

93. Chesnut CH 3rd, Silverman S, Andriano K, Genant H, Gimona A, Harris S, Kiel D, LeBoff M, Maricic M, Miller P, Moniz C, Peacock M, Richardson P, Watts N, Baylink D: A randomized trial of nasal spray salmon calcitonin in postmenopausal women with established osteoporosis: the prevent recurrence of osteoporotic fractures study. PROOF Study Group. Am J Med 2000, 109:267-276

94. Kadono Y, Tanaka S, Nishino J, Nishimura K, Nakamura I, Miyazaki T, Takayanagi H, Nakamura K: Rheumatoid arthritis associated with osteopetrosis. Mod Rheumato/ 2009, 19:687-690.

95. Redlich K, Hayer S, Ricci R, David JP, Tohidast-Akrad M, Kollias G, Steiner G, Smolen JS, Wagner EF, Schett G: Osteoclasts are essential for TNF-alphamediated joint destruction. J Clin Invest 2002, 110:1419-1427.

96. Morko JP, Soderstrom M, Saamanen AM, Salminen HJ, Vuorio El: Up regulation of cathepsin $\mathrm{K}$ expression in articular chondrocytes in a transgenic mouse model for osteoarthritis. Ann Rheum Dis 2004, 63:649-655.

97. Morko J, Kiviranta R, Joronen K, Saamanen AM, Vuorio E, Salminen-Mankonen $H$ : Spontaneous development of synovitis and cartilage degeneration in transgenic mice overexpressing cathepsin K. Arthritis Rheum 2005 , 52:3713-3717

98. Schurigt U, Stopfel N, Huckel M, Pfirschke C, Wiederanders B, Brauer R: Local expression of matrix metalloproteinases, cathepsins, and their inhibitors during the development of murine antigen-induced arthritis. Arthritis Res Ther 2005, 7:R174-R188.

99. Hou WS, Li Z, Gordon RE, Chan K, Klein MJ, Levy R, Keysser M, Keyszer G, Brömme D: Cathepsin k is a critical protease in synovial fibroblastmediated collagen degradation. Am J Pathol 2001, 159:2167-2177.

100. Yasuda Y, Kaleta J, Bromme D: The role of cathepsins in osteoporosis and arthritis: rationale for the design of new therapeutics. Adv Drug Deliv Rev 2005, 57:973-993.

101. Schurigt U, Hummel KM, Petrow PK, Gajda M, Stöckigt R, Middel P, Zwerina J, Janik T, Bernhardt R, Schüler S, Scharnweber D, Beckmann F, Saftig P, Kollias G, Schett G, Wiederanders B, Bräuer R: Cathepsin K deficiency partially inhibits, but does not prevent, bone destruction in human tumor necrosis factortransgenic mice. Arthritis Rheum 2008, 58:422-434.

102. Ainola M, Valleala H, Nykanen P, Risteli J, Hanemaaijer R, Konttinen YT: Erosive arthritis in a patient with pycnodysostosis: an experiment of nature. Arthritis Rheum 2008, 58:3394-3401.

103. Garnero P, Thompson E, Woodworth T, Smolen JS: Rapid and sustained improvement in bone and cartilage turnover markers with the antiinterleukin-6 receptor inhibitor tocilizumab plus methotrexate in rheumatoid arthritis patients with an inadequate response to methotrexate: results from a substudy of the multicenter double-blind, placebo-controlled trial of tocilizumab in inadequate responders to methotrexate alone. Arthritis Rheum 2010, 62:33-43.

104. Syversen SW, Goll GL, van der Heijde D, Landewé R, Gaarder PI, Odegård S, Haavardsholm EA, Kvien TK: Cartilage and bone biomarkers in rheumatoid arthritis: prediction of 10-year radiographic progression. J Rheumatol 2009, 36:266-272.

105. Everts V, de Vries TJ, Helfrich MH: Osteoclast heterogeneity: lessons from osteopetrosis and inflammatory conditions. Biochim Biophys Acta 2009
1792:757-765

106. Delaisse JM, Andersen TL, Engsig MT, Henriksen K, Troen T, Blavier L: Matrix metalloproteinases (MMP) and cathepsin $\mathrm{K}$ contribute differently to osteoclastic activities. Microsc Res Tech 2003, 61:504-513.

107. Hakala M, Risteli J, Aman S, Kautiainen H, Korpela M, Hannonen P, LeirisaloRepo M, Laasonen L, Paimela L, Möttönen T; Fin-Raco Trial Group: Combination drug strategy in recent-onset rheumatoid arthritis suppresses collagen I degradation and is associated with retardation of radiological progression. Scand J Rheumatol 2008, 37:90-93.

108. Ylisirnio S, Sassi ML, Risteli J, Turpeenniemi-Hujanen T, Jukkola A: Serum type I collagen degradation markers, ICTP and CrossLaps, are factors for poor survival in lung cancer. Anticancer Res 1999, 19:5577-5581.

109. Chopin F, Garnero P, le Henanff A, Debiais F, Daragon A, Roux C, Sany J, Wendling D, Zarnitsky C, Ravaud P, Thomas T: Long-term effects of infliximab on bone and cartilage turnover markers in patients with rheumatoid arthritis. Ann Rheum Dis 2008, 67:353-357.

110. Muñoz-Torres M, Reyes-García R, Mezquita-Raya P, Fernández-García D, Alonso G, Luna Jde D, Ruiz-Requena ME, Escobar-Jiménez F: Serum cathepsin $\mathrm{K}$ as a marker of bone metabolism in postmenopausal women treated with alendronate. Maturitas 2009, 64:188-192.

111. Janckila AJ, Neustadt DH, Yam LT: Significance of serum TRACP in rheumatoid arthritis. J Bone Miner Res 2008, 23:1287-1295.

112. Marotte $H$, Gineyts $E$, Miossec P, Delmas PD: Effects of infliximab therapy on biological markers of synovium activity and cartilage breakdown in patients with rheumatoid arthritis. Ann Rheum Dis 2009, 68:1197-1200.

113. Hashimoto J, Garnero P, van der Heijde D, Miyasaka N, Yamamoto K, Kawai S, Takeuchi T, Yoshikawa H, Nishimoto N: Humanized anti-interleukin-6receptor antibody (tocilizumab) monotherapy is more effective in slowing radiographic progression in patients with rheumatoid arthritis at high baseline risk for structural damage evaluated with levels of biomarkers, radiography, and BMI: data from the SAMURAI study. Mod Rheumato/ 2010 21:10-15.

114. Hashimoto J, Garnero P, van der Heijde D, Miyasaka N, Yamamoto K, Kawai S, Takeuchi T, Yoshikawa H, Nishimoto N: A combination of biochemical markers of cartilage and bone turnover, radiographic damage and body mass index to predict the progression of joint destruction in patients with rheumatoid arthritis treated with disease-modifying anti-rheumatic drugs. Mod Rheumatol 2009, 19:273-282.

115. Schett $\mathrm{G}$ : Bone formation versus bone resorption in ankylosing spondylitis. Adv Exp Med Biol 2009, 649:1 14-121.

116. Ruof J, Stucki G: Validity aspects of erythrocyte sedimentation rate and C-reactive protein in ankylosing spondylitis: a literature review. J Rheumatol 1999, 26:966-970.

117. Spoorenberg A, van der Heijde D, de Klerk E, Dougados M, de Vlam K, Mielants $H$, van der Tempel $H$, van der Linden S: Relative value of erythrocyte sedimentation rate and C-reactive protein in assessment of disease activity in ankylosing spondylitis. J Rheumatol 1999, 26:980-984.

118. Maksymowych WP, Dhillon SS, Park R, Salonen D, Inman RD, Lambert RG: Validation of the spondyloarthritis research consortium of Canada magnetic resonance imaging spinal inflammation index: is it necessary to score the entire spine? Arthritis Rheum 2007, 57:501-507.

119. Wanders AJ, Landewé RB, Spoorenberg A, Dougados M, van der Linden S, Mielants $H$, van der Tempel $H$, van der Heijde DM: What is the most appropriate radiologic scoring method for ankylosing spondylitis? A comparison of the available methods based on the Outcome Measures in Rheumatology Clinical Trials filter. Arthritis Rheum 2004, 50:2622-2632.

120. de Vries MK, van Eijk IC, van der Horst-Bruinsma IE, Peters MJ, Nurmohamed MT, Dijkmans BA, Hazenberg BP, Wolbink GJ: Erythrocyte sedimentation rate, $\mathrm{C}$-reactive protein level, and serum amyloid a protein for patient selection and monitoring of anti-tumor necrosis factor treatment in ankylosing spondylitis. Arthritis Rheum 2009, 61:1484-1490.

121. Vandooren B, Kruithof E, Yu DT, Rihl M, Gu J, De Rycke L, Van Den Bosch F, Veys EM, De Keyser F, Baeten D: Involvement of matrix metalloproteinases and their inhibitors in peripheral synovitis and down-regulation by tumor necrosis factor alpha blockade in spondylarthropathy. Arthritis Rheum 2004, 50:2942-2953.

122. Yang C, Gu J, Rihl M, Baeten D, Huang F, Zhao M, Zhang H, Maksymowych WP, De Keyser F, Veys EM, Yu DT: Serum levels of matrix metalloproteinase 3 and macrophage colony-stimulating factor 1 correlate with disease activity in ankylosing spondylitis. Arthritis Rheum 2004, 51:691-699.

123. Maksymowych WP, Landewé $R$, Conner-Spady B, Dougados M, Mielants $H_{\text {, }}$ 
van der Tempel H, Poole AR, Wang N, van der Heijde D: Serum matrix metalloproteinase 3 is an independent predictor of structural damage progression in patients with ankylosing spondylitis. Arthritis Rheum 2007, 56:1846-1853.

124. Maksymowych WP, Rahman P, Shojania K, Olszynski WP, Thomson GT, Ballal S, Wong RL, Inman RD; M03-606 Study Group: Beneficial effects of adalimumab on biomarkers reflecting structural damage in patients with ankylosing spondylitis. J Rheumatol 2008, 35:2030-2037.

125. Kim TH, Stone M, Payne U, Zhang X, lonescu M, LobanokT, King L, Poole AR, Inman RD: Cartilage biomarkers in ankylosing spondylitis: relationship to clinical variables and treatment response. Arthritis Rheum 2005, 52:885-891.

126. Maksymowych WP, Poole AR, Hiebert L, Webb A, lonescu M, Lobanok T, King L, Davis JC Jr: Etanercept exerts beneficial effects on articular cartilage biomarkers of degradation and turnover in patients with ankylosing spondylitis. J Rheumatol 2005, 32:1911-1917.

127. Vosse D, Landewe R, Garnero P, van der HD, van der LS, Geusens P: Association of markers of bone- and cartilage-degradation with radiological changes at baseline and after 2 years follow-up in patients with ankylosing spondylitis. Rheumatology (Oxford) 2008, 47:1219-1222.

128. Franck H, Meurer T, Hofbauer LC: Evaluation of bone mineral density, hormones, biochemical markers of bone metabolism, and osteoprotegerin serum levels in patients with ankylosing spondylitis. J Rheumatol 2004, 31:2236-2241.

129. Verstappen SM, Poole AR, lonescu M, King LE, Abrahamowicz M, Hofman DM, Bijlsma JW, Lafeber FP; Utrecht Rheumatoid Arthritis Cohort Study group (SRU): Radiographic joint damage in rheumatoid arthritis is associated with differences in cartilage turnover and can be predicted by serum biomarkers: an evaluation from 1 to 4 years after diagnosis. Arthritis Res Ther 2006, 8:R31.

130. Garnero P, Landewé R, Boers M, Verhoeven A, Van Der Linden S, Christgau S, Van Der Heijde D, Boonen A, Geusens P: Association of baseline levels of markers of bone and cartilage degradation with long-term progression of joint damage in patients with early rheumatoid arthritis: the COBRA study. Arthritis Rheum 2002, 46:2847-2856.

131. Landewé R, Geusens P, Boers M, van der Heijde D, Lems W, te Koppele J, van der Linden S, Garnero P: Markers for type II collagen breakdown predict the effect of disease-modifying treatment on long-term radiographic progression in patients with rheumatoid arthritis. Arthritis Rheum 2004, 50:1390-1399

132. Landewe RB, Geusens P, van der Heijde DM, Boers M, van der Linden SJ, Garnero P: Arthritis instantaneously causes collagen type I and type II degradation in patients with early rheumatoid arthritis: a longitudinal analysis. Ann Rheum Dis 2006, 65:40-44.

133. Garnero $P$, Mazières $B$, Guéquen A, Abbal M, Berdah L, Lequesne M, Nguyen $M$, Salles JP, Vignon E, Dougados M: Cross-sectional association of 10 molecular markers of bone, cartilage, and synovium with disease activity and radiological joint damage in patients with hip osteoarthritis: the ECHODIAH cohort. J Rheumatol 2005, 32:697-703.

134. Mazières B, Garnero P, Guéguen A, Abbal M, Berdah L, Lequesne M, Nguyen $M$, Salles JP, Vignon E, Dougados M: Molecular markers of cartilage breakdown and synovitis at baseline as predictors of structural progression of hip osteoarthritis. The ECHODIAH Cohort. Ann Rheum Dis 2006, 65:354-359.

135. Shinozaki M, Inoue E, Nakajima A, Hara M, Tomatsu T, Kamatani N, Yamanaka $\mathrm{H}$ : Elevation of serum matrix metalloproteinase-3 as a predictive marker for the long-term disability of rheumatoid arthritis patients in a prospective observational cohort IORRA. Mod Rheumato/ 2007, 17:403-408.

136. Christensen AF, Lottenburger T, Lindegaard H, Christgau S, Horslev-Petersen $K$, Junker P: Differential association of the N-propeptide of collagen IIA (PIIANP) and collagen II C-telopeptide (CTX-II) with synovitis and erosions in early and longstanding rheumatoid arthritis. Clin Exp Rheumatol 2009, 27:307-314.

137. Garnero P, Jouvenne P, Buchs N, Delmas PD, Miossec P: Uncoupling of bone metabolism in rheumatoid arthritis patients with or without joint destruction: assessment with serum type I collagen breakdown products. Bone 1999, 24:381-385.

138. Cohen SB, Emery P, Greenwald MW, Dougados M, Furie RA, Genovese MC, Keystone EC, Loveless JE, Burmester GR, Cravets MW, Hessey EW, Shaw T, Totoritis MC; REFLEX Trial Group: Rituximab for rheumatoid arthritis refractory to anti-tumor necrosis factor therapy: Results of a multicenter, randomized, double-blind, placebo-controlled, phase III trial evaluating primary efficacy and safety at twenty-four weeks. Arthritis Rheum 2006, 54:2793-2806.

139. Bauer DC, Hunter DJ, Abramson SB, Attur M, Corr M, Felson D, Heinegård D, Jordan JM, Kepler TB, Lane NE, Saxne T, Tyree B, Kraus VB; Osteoarthritis Biomarkers Network: Classification of osteoarthritis biomarkers: a proposed approach. Osteoarthritis Cartilage 2006, 14:723-727.

140. Schett G, Smolen JS: New insights in the mechanism of bone loss in arthritis. Curr Pharm Des 2005, 11:3039-3049.

141. Landewe R: Predictive markers in rapidly progressing rheumatoid arthritis. J Rheumatol Supp/ 2007, 80:8-15.

142. Bay-Jensen AC, Liu Q, Byrjalsen I, Li Y, Wang J, Pedersen C, Leeming DJ, Dam EB, Zheng Q, Qvist P, Karsdal MA: Enzyme-linked immunosorbent assay (ELISAs) for metalloproteinase derived type II collagen neoepitope, CIIMIncreased serum CIIM in subjects with severe radiographic osteoarthritis. Clin Biochem 2011, 44:423-429.

143. Pratta MA, Su JL, Leesnitzer MA, Struglics A, Larsson S, Lohmander LS, Kumar S: Development and characterization of a highly specific and sensitive sandwich ELISA for detection of aggrecanase-generated aggrecan fragments. Osteoarthritis Cartilage 2006, 14:702-713.

144. Glant TT, Mikecz K, Poole AR: Monoclonal antibodies to different proteinrelated epitopes of human articular cartilage proteoglycans. Biochem J $1986,234: 31-41$

145. Glant TT, Mikecz K, Roughley PJ, Buzas E, Poole AR: Age-related changes in protein-related epitopes of human articular-cartilage proteoglycans. Biochem J 1986, 236:71-75.

146. Rousseau JC, Sumer EU, Hein G, Sondergaard BC, Madsen SH, Pedersen C, Neumann T, Mueller A, Qvist P, Delmas P, Karsdal MA: Patients with rheumatoid arthritis have an altered circulatory aggrecan profile. BMC Musculoskelet Disord 2008, 9:74.

147. Smolen JS, Van Der Heijde DM, St Clair EW, Emery P, Bathon JM, Keystone E, Maini RN, Kalden JR, Schiff M, Baker D, Han C, Han J, Bala M; Active-Controlled Study of Patients Receiving Infliximab for the Treatment of Rheumatoid Arthritis of Early Onset (ASPIRE) Study Group: Predictors of joint damage in patients with early rheumatoid arthritis treated with high-dose methotrexate with or without concomitant infliximab: results from the ASPIRE trial. Arthritis Rheum 2006, 54:702-710.

148. Jansen LM, van der Horst-Bruinsma IE, van SD, Bezemer PD, Dijkmans BA: Predictors of radiographic joint damage in patients with early rheumatoid arthritis. Ann Rheum Dis 2001, 60:924-927.

149. Catrina Al, Lampa J, Ernestam S, af Klint E, Bratt J, Klareskog L, Ulfgren AK: Anti-tumour necrosis factor (TNF)-alpha therapy (etanercept) downregulates serum matrix metalloproteinase (MMP)-3 and MMP-1 in rheumatoid arthritis. Rheumatology (Oxford) 2002, 41:484-489.

150. Vilim V, Lenz ME, Vytasek R, Masuda K, Pavelka K, Kuettner KE, Thonar EJ: Characterization of monoclonal antibodies recognizing different fragments of cartilage oligomeric matrix protein in human body fluids. Arch Biochem Biophys 1997, 341:8-16.

151. Muller G, Michel A, Altenburg E: COMP (cartilage oligomeric matrix protein) is synthesized in ligament, tendon, meniscus, and articular cartilage. Connect Tissue Res 1998, 39:233-244.

152. Marti C, Neidhart M, Gerber T, Hauser N, Michel BA, Hauselmann HJ: [Cartilage oligomeric matrix protein (COMP): the role of a non-collagen cartilage matrix protein as a marker of disease activity and joint destruction in patients with rheumatoid arthritis and osteoarthritis]. ZRheumatol 1999, 58:79-87.

153. Skoumal M, Kolarz G, Klingler A: Serum levels of cartilage oligomeric matrix protein. A predicting factor and a valuable parameter for disease management in rheumatoid arthritis. Scand J Rheumatol 2003, 32:156-161.

154. de Jong Z, Munneke M, Vilim V, Zwinderman AH, Kroon HM, Ronday HK, Lems WF, Dijkmans BA, Breedveld FC, Vliet Vlieland TP, Hazes JM, Degroot J: Value of serum cartilage oligomeric matrix protein as a prognostic marker of large-joint damage in rheumatoid arthritis--data from the RAPIT study. Rheumatology (Oxford) 2008, 47:868-871.

155. Fujikawa K, Kawakami A, Tamai M, Uetani M, Takao S, Arima K, Iwamoto N, Aramaki T, Kawashiri S, Ichinose K, Kamachi M, Nakamura H, Origuchi T, Ida H, Aoyagi K, Eguchi K: High serum cartilage oligomeric matrix protein determines the subset of patients with early-stage rheumatoid arthritis with high serum C-reactive protein, matrix metalloproteinase-3, and MRI-proven bone erosion. J Rheumatol 2009, 36:1126-1129.

156. Melkko J, Niemi S, Risteli L, Risteli J: Radioimmunoassay of the carboxyterminal propeptide of human type I procollagen. Clin Chem 1990, 
36:1328-1332

157. Melkko J, Kauppila S, Niemi S, Risteli L, Haukipuro K, Jukkola A, Risteli J: Immunoassay for intact amino-terminal propeptide of human type I procollagen. Clin Chem 1996, 42:947-954.

158. Garnero P, Aronstein WS, Cohen SB, Conaghan PG, Cline GA, Christiansen C, Beary JF, Meyer JM, Bingham CO 3rd: Relationships between biochemical markers of bone and cartilage degradation with radiological progression in patients with knee osteoarthritis receiving risedronate: the Knee Osteoarthritis Structural Arthritis randomized clinical trial. Osteoarthritis Cartilage 2008, 16:660-666.

159. Hanson DA, Weis MA, Bollen AM, Maslan SL, Singer FR, Eyre DR: A specific immunoassay for monitoring human bone resorption: quantitation of type I collagen cross-linked N-telopeptides in urine. J Bone Miner Res 1992 7:1251-1258.

160. Elomaa I, Virkkunen P, Risteli L, Risteli J: Serum concentration of the crosslinked carboxyterminal telopeptide of type I collagen (ICTP) is a useful prognostic indicator in multiple myeloma. Br J Cancer 1992, 66:337-341.

161. Nelson F, Dahlberg L, Laverty S, Reiner A, Pidoux I, lonescu M, Fraser GL, Brooks E, Tanzer M, Rosenberg LC, Dieppe P, Robin Poole A: Evidence for altered synthesis of type II collagen in patients with osteoarthritis. J Clin Invest 1998, 102:2115-2125.

162. Downs JT, Lane CL, Nestor NB, McLellan TJ, Kelly MA, Karam GA, Mezes PS, Pelletier JP, Otterness IG: Analysis of collagenase-cleavage of type II collagen using a neoepitope ELISA. J Immunol Methods 2001, 247:25-34

163. Lohmander LS, Atley LM, Pietka TA, Eyre DR: The release of crosslinked peptides from type II collagen into human synovial fluid is increased soon after joint injury and in osteoarthritis. Arthritis Rheum 2003, 48:3130-3139.

164. Eyre DR, Weis MA: The Helix-II epitope: a cautionary tale from a cartilage biomarker based on an invalid collagen sequence. Osteoarthritis Cartilage 2009, 17:423-426.

165. Charni N, Juillet F, Garnero P: Urinary type II collagen helical peptide (HELIXII) as a new biochemical marker of cartilage degradation in patients with osteoarthritis and rheumatoid arthritis. Arthritis Rheum 2005, 52:1081-1090.

166. Garnero P, Desmarais S, Charni N, Percival MD: The type Il collagen fragments HELIX-II and CTX-II reveal distinct enzymatic pathways of cartilage collagen degradation: diagnostic and therapeutic implications in rheumatoid arthritis and osteoarthritis. Arthritis Rheum 2005, 44(Suppl):S56.

167. Poole AR, lonescu M, Fitzcharles MA, Billinghurst RC: The assessment of cartilage degradation in vivo: development of an immunoassay for the measurement in body fluids of type II collagen cleaved by collagenases. $\mathrm{J}$ Immunol Methods 2004, 294:145-153.

168. Billinghurst RC, Mwale F, Hollander A, lonescu M, Poole AR: Immunoassays for collagens in chondrocyte and cartilage explant cultures. Methods $\mathrm{Mol}$ Med 2004, 100:251-274.

169. Billinghurst RC, Dahlberg L, lonescu M, Reiner A, Bourne R, Rorabeck C, Mitchell P, Hambor J, Diekmann O, Tschesche H, Chen J, Van Wart H, Poole AR: Enhanced cleavage of type II collagen by collagenases in osteoarthritic articular cartilage. J Clin Invest 1997, 99:1534-1545.

170. Risteli J, Niemi S, Trivedi P, Maentausta O, Mowat AP, Risteli L: Rapid equilibrium radioimmunoassay for the amino-terminal propeptide of human type III procollagen. Clin Chem 1988, 34:715-718.

171. Gineyts E, Garnero P, Delmas PD: Urinary excretion of glucosyl-galactosyl pyridinoline: a specific biochemical marker of synovium degradation. Rheumatology (Oxford) 2001, 40:315-323.

172. Johansen JS, Jensen HS, Price PA: A new biochemical marker for joint injury. Analysis of YKL-40 in serum and synovial fluid. Br J Rheumatol 1993, 32:949-955

173. Green MJ, Gough AK, Devlin J, Smith J, Astin P, Taylor D, Emery P: Serum MMP-3 and MMP-1 and progression of joint damage in early rheumatoid arthritis. Rheumatology (Oxford) 2003, 42:83-88

174. Keyszer G, Lambiri I, Nagel R, Keysser C, Keysser M, Gromnica-Ihle E, Franz J, Burmester GR, Jung K: Circulating levels of matrix metalloproteinases MMP-3 and MMP-1, tissue inhibitor of metalloproteinases 1 (TIMP-1), and MMP-1/TIMP-1 complex in rheumatic disease. Correlation with clinical activity of rheumatoid arthritis versus other surrogate markers. J Rheumatol 1999, 26:251-258.
175. Voorzanger-Rousselot N, Ben-Tabassi NC, Garnero P: Opposite relationships between circulating Dkk-1 and cartilage breakdown in patients with rheumatoid arthritis and knee osteoarthritis. Ann Rheum Dis 2009, 68:1513-1514

176. Gaudio A, Pennisi P, Bratengeier C, Torrisi V, Lindner B, Mangiafico RA, Pulvirenti I, Hawa G, Tringali G, Fiore CE: Increased sclerostin serum levels associated with bone formation and resorption markers in patients with immobilization-induced bone loss. J Clin Endocrinol Metab 2010, 95:2248-2253.

177. Nenonen A, Cheng S, Ivaska KK, Alatalo SL, Lehtimäki T, Schmidt-Gayk H, Uusi-Rasi K, Heinonen A, Kannus P, Sievänen H, Vuori I, Väänänen HK, Halleen $J M$ : Serum TRACP $5 b$ is a useful marker for monitoring alendronate treatment: comparison with other markers of bone turnover. J Bone Miner Res 2005, 20:1804-1812.

178. Rissanen JP, Suominen MI, Peng Z, Halleen JM: Secreted tartrate-resistant acid phosphatase $5 \mathrm{~b}$ is a Marker of osteoclast number in human osteoclast cultures and the rat ovariectomy model. Calcif Tissue Int 2008, 82:108-115.

179. Qvist P, Christiansen C, Karsdal MA, Madsen SH, Sondergaard BC, Bay-Jensen AC: Application of biochemical markers in development of drugs for treatment of osteoarthritis. Biomarkers 2010, 15:1-19.

180. Syversen SW, Haavardsholm EA, Bøyesen P, Goll GL, Okkenhaug C, Gaarder PI, van der Heijde D, Kvien TK: Biomarkers in early rheumatoid arthritis: longitudinal associations with inflammation and joint destruction measured by magnetic resonance imaging and conventional radiographs. Ann Rheum Dis 2010, 69:845-850.

181. Garnero P, Peterfy C, Zaim S, Schoenharting M: Bone marrow abnormalities on magnetic resonance imaging are associated with type II collagen degradation in knee osteoarthritis: a three-month longitudinal study. Arthritis Rheum 2005, 52:2822-2829.

182. Knudsen LS, Klarlund M, Skjødt H, Jensen T, Ostergaard M, Jensen KE, Hansen MS, Hetland ML, Nielsen HJ, Johansen JS: Biomarkers of inflammation in patients with unclassified polyarthritis and early rheumatoid arthritis. Relationship to disease activity and radiographic outcome. J Rheumatol 2008, 35:1277-1287.

183. Karsdal MA, Byrjalsen I, Azria M, Arnold M, Choi L, Riis BJ, Christiansen C: Influence of food intake on the bioavailability and efficacy of oral calcitonin. Br J Clin Pharmacol 2009, 67:413-420.

184. Andersson ML, Petersson IF, Karlsson KE, Jonsson EN, Månsson B, Heinegård D, Saxne T: Diurnal variation in serum levels of cartilage oligomeric matrix protein in patients with knee osteoarthritis or rheumatoid arthritis. Ann Rheum Dis 2006, 65:1490-1494.

185. Karsdal MA, Byrjalsen I, Riis BJ, Christiansen C: Investigation of the diurnal variation in bone resorption for optimal drug delivery and efficacy in osteoporosis with oral calcitonin. BMC Clin Pharmacol 2008, 8:12.

186. Kong SY, Stabler TV, Criscione LG, Elliott AL, Jordan JM, Kraus VB: Diurnal variation of serum and urine biomarkers in patients with radiographic knee osteoarthritis. Arthritis Rheum 2006, 54:2496-2504.

187. Quintana DJ, Garnero P, Huebner JL, Charni-Ben TN, Kraus VB: PIIANP and HELIXII diurnal variation. Osteoarthritis Cartilage 2008, 16:1192-1195.

188. Schlemmer A, Hassager C, Jensen SB, Christiansen C: Marked diurnal variation in urinary excretion of pyridinium cross-links in premenopausal women. J Clin Endocrinol Metab 1992, 74:476-480.

189. Criscione LG, Elliott AL, Stabler T, Jordan JM, Pieper CF, Kraus VB: Variation of serum hyaluronan with activity in individuals with knee osteoarthritis. Osteoarthritis Cartilage 2005, 13:837-840.

190. Gordon CD, Stabler TV, Kraus VB: Variation in osteoarthritis biomarkers from activity not food consumption. Clin Chim Acta 2008, 398:21-26.

doi:10.1186/ar3280

Cite this article as: Karsdal MA, et al:: Biochemical markers of ongoing joint damage in rheumatoid arthritis - current and future applications, limitations and opportunities. Arthritis Research \& Therapy 2011, 13:215. 